\title{
Tabust saab kommunikatsioon: dopinguteemaline huumor kultuuride dialoogis
}

\author{
Liisi Laineste \\ Eesti Kirjandusmuuseumi folkloristika osakonna vanemteadur \\ liisi.laineste@folklore.ee \\ Piret Voolaid \\ Eesti Kirjandusmuuseumi folkloristika osakonna vanemteadur, \\ Eesti-uuringute Tippkeskuse tegevjuht \\ piret.voolaid@folklore.ee
}

Teesid: Internet mõjutab huumori tõlkimist mitmel moel, avaldades toimet näiteks tekstide levikukiirusele, aga ka sisule. Selle meedialiigi mõjud on eriti ilmsed siis, kui taaskasutatakse - kohandatakse ja tõlgitakse - peamiselt ingliskeelsetest nalja- ja meemikogumitest pärinevaid tekste.

Artiklis antakse ülevaade dopingukasutamise kui vaikimise ja varjamisega seotud tabulise käitumise ja sellega seotud hoiakute kajastamisest internetimeemides, võrreldes kahte korpust, mis hõlmavad kahte rahvusvahelise mõõtmega dopingujuhtumit. 2012. aastal aset leidnud Lance Armstrongi ja 2019. aasta veebruaris Seefeldis põhja suusaalade maailmameistrivõistlustel lahvatanud Aadrilaskmise juhtumitega seotud meemikorpusi analüüsitakse globaalsest ja lokaalsest vaatenurgast, et välja selgitada korduvaid mustreid ja erinevusi ning mõtestada seeläbi huumori sisu ja vormi mõjutavaid levikuprotsesse. Kahte juhtumit käsitleme kohalikul ja üleilmsel tasandil väljenduva kultuuritõlke protsessina. Analüüsi aluseks on Limor Shifmani meemiuurimused ja Sara Cannizzaro (2016) kultuurisemiootiline tõlketeooria, mis põhineb Juri Lotmani töödel ja tugineb väitele, et igasugust teadmist võib vaadelda pideva semiootilise "sissetungina" "teise territooriumi" struktuuridesse (Lotman 1992), mille tulemusena sünnib loominguline kohanemine. Uurimus annab kahe dopinguskandaali meemiainese näitel aimu semiootiliste ühikute - meemide - kohanemismehhanismide kohta veebikeskkonnas.

Märksõnad: dopingufolkloor, folkloristika, huumor, kultuurisemiootiline tõlge, spordifolkloor, spordimeemid

\section{Sissejuhatus}

Veebisuhtlus, mis võimaldab teabe kiiremat ja laiemat levikut, peegeldab ühtlasi globaliseerumise ja lokaliseerimisega seotud pingevälju (Cronin 2003: 10-17). Need pinged avalduvad ka huumorivormis. Uues meedias leviva huumori 
tõlkemehhanismid on hästi jälgitavad väikestes keeltes, mis kohandavad oma keele- ja kultuuriruumile suurte (enamasti ingliskeelsete) meemikogumite tekste (Coscia 2013: 100-101). Võitlus kujundlikult öeldes digitaalse džungli nutikaima tiitlile - ehk siis selle nimel, kes suudab postitada parima meemi motiveerib internetikasutajaid leidma parimat sisu, seda ümber tegema ja kohandama. Selleks pöördutakse eri veebikeskkondades ja keeltes leiduvate allikate poole, millega ollakse varem tuttavad või kokku puutunud ning ammutatakse muudest kontekstidest meemide sisu ja vormi.

Artikli eesmärk on analüüsida meemide tõlkemehhanisme ja toimesuundi (globaalsest lokaalseks ja/või vastupidi) ehk siis protsessi, mis on tänapäeva veebikultuuri kohanemise nurgakivi. Kirjeldades humoorikates meemides leiduvaid korduvaid ja erandlikke mustreid tuvastame nii hõlpsasti kohandatavad kui ka tõlkimatud elemendid. Nende infoväärtus ja olulisus auditooriumile ning kasutatavad huumorimehhanismid on eduka levitamise aluseks. Uuringus käsitleme järgmisi küsimusi: millised teemad korduvad ülemaailmselt ja millised on eelkõige kohalikud? Milliseid globaalseid ja kohalikke popkultuuri narratiive kasutatakse meemide konstrueerimisel? Kui hästi saab meeme tõlkida globaalsest kontekstist kohalikku? Mis on tõlkimatuse peamised põhjused? Milliseid huumorimehhanisme kasutatakse kõige sagedamini? Nendele küsimustele saadud vastused aitavad selgitada meemide kohanemist kultuurilise tõlke protsessis.

Juhtumianalüüs keskendub 2012. aastal ja 2019. aastal lahvatanud dopinguskandaalidele ning neile järgnenud meemiloome puhangutele internetis. Esimene neist võttis sihikule USA jalgratturi Lance Armstrongi (sünd 1971), kes alustas oma profiratturi karjääri 1992. aastal ja saavutas sel alal märkimisväärset edu. Temast sai kogu maailmas tuntud spordikangelane. 1995. aastal diagnoositi tal vähk, mille ravi osutus edukaks. Sangari positsiooni tugevdas positiivne ühiskondlik kuvand: näiteks asutas ta vähiravijärgsele taastumisele suunatud heategevusfondi Livestrong. 2012. aastal aga tunnistati Armstrong süüdi dopingu pruukimises ja talle määrati eluaegne võistluskeeld kõigil spordialadel. Teine juhtum puudutab Eesti olümpiamedalisti Andrus Veerpalu (keda ennast süüdistati 2011. aastal dopingutarvitamises; vt Voolaid \& Laineste 2013) poega Andreas Veerpalu (sünd 1994) ja Karel Tammjärve (sünd 1989). Kaks viimatinimetatut vahistati 2019. aasta veebruaris Austrias Tiroolis Seefeldis põhja suusaalade maailmameistrivõistlustel politseioperatsiooni Aadrilaskmine (Aderlass) käigus. Mõlemad noorsuusatajad vahistati koos viie teise suusatajaga kahtlustatuna hapnikuga rikastatud vereülekannete, nn veredopingu tarvitamises, et parandada oma sportlikku võimekust, mida nad hiljem ka ise tunnistasid. 


\section{Huumor globaliseeruvas maailmas}

Huumor ei ületa riigi- ja keelepiire alati edukalt, sest ühes kultuuriümbruses sündinud nalja võib olla raske mõista väljaspool talle omast konteksti (vt ka Lu et al. 2019). Globaalse maailma tingimustes laiendavad aga inimesed pidevalt oma huumorirepertuaari tekstide ja piltidega, mis on loodud väljaspool nende kultuuri, eriti inglise keelt emakeelena mittekõnelevas maailmas. Kuna tihenevad (ehkki mõnikord ainult digitaalsed) kontaktid laieneva semiosfääriga, suurenevad pidevalt võimalused, et tekste nopitakse globaalsest meemikogumist ja kohandatakse kohalikele vajadustele (Shifman \& Thelwall 2009; Shifman 2014: 154-170; Laineste \& Voolaid 2016).

Meemide viraalsuse uuringud on näidanud, et üldjuhul eelistavad inimesed naljaka ja emotsionaalselt laetud sisu edastamist (nt Berger \& Milkman 2012; Kim 2015; Johann \& Bülow 2018) faktiliselt asjalikule ja neutraalsele sisule. Tim Highfield (2015: 2729) on kirjeldanud, kuidas "peavoolu uudisteallikad postitavad uudiste osana humoorikaid säutse, lisades oma kommentaaridesse pilget. [...] Huumor oma teemade ja allikatega võib meelitada kirjutama lisakommentaare ja inspireerida uudislugude teemade ja allikatega seotud osalusvorme". Huumoriga vürtsitatud sisu pole muidugi uus nähtus (Frank 2011), kuid uudisfolkloorse veebisuhtluse iseloomulik uus tunnus on selle ulatus, kaalukus ja võimekus levida otsekohe, olenemata originaalkeelest (vt ka Highfield \& Leaver 2016). See saab võimalikuks uute tehniliste lahenduste toel - rolli mängivad seadmete ja andmesideühenduste kiirus ja leviulatus ükskõik millises maailma osas ning sotsiaalmeedia voogedastus. Oluline on märkida, et memeetilist huumorit iseloomustab üldiselt mitte ülivõrdeliselt positiivne, vaid pigem sardooniline toon (vt ka Milner 2013). Audiovisuaalse lahenduse afektiivne väärtus on toetanud skandaalidest ja katastroofikeskustest pärit teadete kiiret levikut (Hjorth \& Burgess 2014; Vis et al. 2013). Uudiste üks võimalikke visuaalseid väljundeid on internetimeemid, mis on humoorika olemuse tõttu ülipopulaarsed ja toimivad kollektiivse tegevuse laiapõhjalise väljendusvormina (Shifman 2014: 122-123), eriti kehtib see aktuaalsete teemadega (poliitika, kuulsused või sport) seotud skandaalide kohta.

Käesolevas folkloristlikus käsitluses määratleme meeme Limor Shifmani (2014) definitsioonist lähtuvalt (post)modernse folkloorina, mis väljendab ja kujundab ühiseid norme ja väärtusi kogukondades ja pärimusrühmades ning neist väljaspool. Meemitsüklid (Jorgensen 2017) on omakorda samasisuliste meemide konglomeraadid, mis levivad mingi sündmuse ajal ja järel, saavutavad haripunkti ning vaibuvad teema aktuaalsuse lahtumise järel tavaliselt mõne nädala jooksul. Meemid on palju enamat kui meelelahutus; paljud teadusuuringud on näidanud, et meeme kasutatakse nende performatiivsuse ja osalust 
võimaldava vormi tõttu mitmesugustel eesmärkidel, näiteks emotsioonide, pingete ja hoiakute väljendamiseks, kogukonna loomiseks või poliitiliseks protestimiseks (Shifman 2014; Highfield \& Leaver 2016; Veszelszki 2014; Takovski 2016). Meemide uurimise lisaväärtus tuleneb asjaolust, et meemid levivad globaalselt, seda osaliselt oma pildilise olemuse tõttu. Meemide sümboolne keerukus võimendab digisuhtluse kahte põhiaspekti: tundepuhangute esitamist ja kultuuriteadmiste demonstreerimist (Miltner \& Highfield 2017). Internetikasutajad kohandavad meeme vastavalt uutele kultuuri- ja keeleoludele, et neid võimalikule vaatajaskonnale lähemale tuua ja tagada nende kiire levitamine.

Eckart Voigtsi (2017) väitel on kultuuritekstide kohandamine kõige paremini kirjeldatav kui struktuuriliselt muutuvate protokollide või skriptide varieerumine. Kuid meemi kohandamise keskne element ei ole ainult skript ise, vaid selle esituskontekst: tervikprotsess, mis vastab küsimustele kes, kus, miks ja kuidas. See annab märku vajadusest pöörduda hermeneutikast performatiivsete uurimisviiside juurde. Internet pakub lõputut hulka tekstivariante ja enamik seal nähtavast sisust on tõlge millestki, mis seal juba varem on olnud (vt allpool arutelu tõlkimise kui peamise kohandamismehhanismi kohta, ka Cannizzaro 2013). Kohandamine toimub keelelis-kultuurilise tõlke kaudu (Szerszunowicz 2018), võttes arvesse mitte ainult tekstilist külge, vaid ka uude ümbrusse kohandamisel vajalikke kultuurilisi muudatusi. Ehkki meemimallides valitsevad Ameerika ja Lääne popkultuur, eksisteerib palju kohalikke malle (nt hiinakeelsetes meemides; vt Shifman \& Levy \& Thelwall 2014). Asaf Nissenbaum ja Limor Shifman (2018: 306) viitavad, et "kohalikud seaded määravad sisu ja hoiakud, mida meemimallid edastavad", mistõttu isegi kui meemid ekspluateerivad globaalseid malle ja esitavad ülemaailmselt tuntud viiteid näiteks Ameerika popkultuurile (tuntud filmi, näitleja kujutis jne), kasutatakse neid sageli lihtsalt taustana, mille abil kujutada ja kommenteerida kohalikke sündmusi.

Tõlkeuuringutes võib kultuuri vaadelda põhilise analüütilise kategooriana (Delabastita 2002). Margherita Dore (2019) on analüüsinud huumori tõlkimise suundumusi tänapäeval, pöörates tähelepanu rahvusvahelistele arusaamatustele ja väärtõlgetele, mis tekitavad koomilise efekti. Tõlkehuumor põhineb kahe või enama keele omavahelisel mängul, mis loob kontraste ja vallandab koomilise segaduse (vt Chiaro \& De Bonis 2019). Uurides huumorit ja selle keelt digiajastul, kinnitab Delia Chiaro (2018: 3-5), et veebikeskkond on võimendanud huumori ringlemist tänapäeval, kusjuures nalja kohanemine peab toimuma kiiresti ja vastama seejuures väga mitmekesise vaatajaskonna ootustele. Siinses uurimuses huvitavadki meid huumorimotiivide kohandamise ("tõlkimise") ja levitamise mehhanismid keeltes ja kultuurides. Meid huvitab ka naljade tekstuur (Dundes 1964), kus sõnalised elemendid (riim, alliteratsioon, keelespetsiifilised foneemid ja morfeemid jne) moodustavad tõlkimatu 
kihi, mis levib harva ühest keelest teise, eriti kui tegu pole sugulaskeeltega. Meie folkloristlik eesmärk on mõista tekstide levitamise loogikat kui protsessi, milles mängivad olulist rolli nii loovus kui ka väljakujunenud tavad ja reeglid. Tõlkeuuringute ja folkloristika vahel on mitmeid kokkupuutepunkte, näiteks vahendaja rollis olev tõlkija/(folkloori)esitaja ja neile omane loomingulisus.

\section{Semiootiline pilguheit meemide tõlkimisele}

Kohandades meeme ja rekonstrueerides sõnumit vastavalt omaenda kultuurisüsteemile, tegelevad internetikasutajad kultuuritekstide tõlkimisega (Shifman 2014: 354). Selline interpreteeriv osalus näitab, et mõiste "tõlkimine" on protsessi kirjeldamiseks sobiv, sest see "annab rohkem ruumi sellise loovuse kirjeldamiseks, mida on tarvis internetimeemide tegemisel" (Cannizzaro 2016: 574). Seega võib internetimeeme pidada tõlgitavate märkide süsteemideks (ibid.). Tõlke loovuse tingib lähte- ja sihtkultuuride asümmeetria (vt ka Lotman 2001: 14). Üldiselt ei tähenda tõlkimine alati või ainuüksi keelevahetust, asjakohasem on seda näha kui liikumist kultuurikontekstide vahel.

Nii meemiuurijad kui ka semiootikud jälgivad kultuurinähtuste levikumustreid ning kultuurispetsiifilisi piiranguid ja eeliseid. Mõlema aluseks on pakkuda kultuurinähtusi kaasavate protsesside tervikkirjeldust (vt ka Voigts 2017). Semiootikas käivitasid selle lähenemise 1980. aastatel Thomas Sebeoki (1991/1988) ja Itamar Even-Zohari (1986) tööd. Kaks aastakümmet enne seda, vältimaks kultuuri käsitlemist pelgalt selle osade summana, tegi Juri Lotman ettepaneku kasutada mõistet "semiosfäär" (Lotman 1992; vt ka Cannizzaro 2016: 571). Semiosfäär ehk tähendusruum on märkide süsteem, milles kõik elemendid on omavahel seotud ja aitavad kaasa semioosile ehk märgiprotsessile. Sarnase tähelepaneku tegi aastakümneid tagasi ka Julia Kristeva, kes väitis, et kõik tekstid on omavahel seotud, st kõik tekstid on intertekstid (Kristeva 1984). Sellest alates on semiootika püüelnud kultuurimärkide üha integreerituma ja intertekstuaalsema uurimise poole, samal ajal kui meemide uurimine keskendus üksuste piiritlemisele ja nende leviku kirjeldamisele (nt Highfield 2015). Kuid mitte ainult meemiüksused, vaid ka neid ümbritsev keskkond aitab nende tööviisi mõista ja kirjeldada. Cannizzaro (2016: 571) väitel näib teave olevat pigem süsteemne, mitte aatomiline. See viitab tõsiasjale, et kui meemid rändavad uude kultuurikeskkonda, muutub midagi enamat kui keel ja sõnad. Meem kui kultuuriüksus läbib keeruka kohandamisprotsessi, milles arvukad intertekstuaalsed elemendid mängivad tulemuse kujundamisel kaudset rolli. Vaadates meemi kui keelelis-kultuurilise tõlke kaudu (ümber)konstrueeritud (Cannizzaro 2013) kultuuriinfo ühikut, tõstetakse esile kontekstilist vaatenurka 
ja välditakse selliseid mõisteid nagu "remiksimine", "kopeerimine" või "kollaaž", mis pakuksid nähtusest liigselt lihtsustatud pilti (Lessig 2008; vt nende terminite sobivuse arutelu Knobel \& Lankshear 2007). Selline vaatenurga muutus võimaldab meemide analüüsi semiootilise terminoloogia abil, mis oleks eriti kasulik meemide leviku uurimisel.

\section{Spordiskandaalid ja meemid}

Tippsportlased on sarnaselt teiste kuulsuste ja poliitikutega avaliku elu tegelased, kes on selleks ise vabatahtlikult sammu astunud või tähelepanu keskpunkti tõmmatud. Skandaalidest inspireeritud huumor jäljendab tavaliselt olemasolevaid naljavormeleid, esinemispraktikaid (Burroughs \& Vogan 2015) ja strateegiaid, nt tuttavaid teemaarendusi ja lõpplahendusi (vt Blank 2016: 153), aga ka tuntud meemimalle. Trevor Blank (2016) kirjeldab Penn State'i ülikoolis toimunud Sandusky skandaalile järgnenud nalju, mida on jaganud nii spordifännid kui ka pealtvaatajad. Varasemate naljatekstide kohandamine ei vajanud siin keelelist tõlget, kuid neid oli vaja kohandada või tõlkida ühest sündmuskontekstist teise. Blank märgib, kuidas "selle esilekerkiva huumori sisu ja/või eesmärgid sisaldavad sageli viiteid inimestele, toodetele ja konkreetsetele uudissündmustele, mis levivad ühtaegu tänapäeva massimeedias ja populaarkultuuris" (ibid.: 149). Nali täidab kritiseerimise ja kommenteerimise funktsiooni, rõhutades loojate teadlikkust ja oskust kohandada rahva- ja popkultuuri intertekstuaalseid viiteid uutele olukordadele. Oluliseks võimeks, mis huumoriloojaid innustab, on suutlikkus monteerida materjale ühiselt "uuteks" naljadeks ja meemideks. Seetõttu nendib Blank, et tuntud mudelite kohandamine või kultuuriline tõlkimine uutesse kasutuskontekstidesse pole ajendatud mugavusest, vaid peamiselt staatuse ja kogukonnaga seotud aspektidest.

Mõlemad artiklis käsitletavad dopingujuhtumid on sarnased nende avaliku huvi poolest, kuigi sündmustega kursis oleva avalikkuse ulatus on mõnevõrra erinev. Arutades aktiivselt "langenud kangelaste" süütuse, süü, kõlbluse ja isikuomaduste üle, avastas ja kohandas avalikkus oma seisukohtade väljendamiseks uusi ja nutikaid, sageli humoorikaid viise. Highfield (2015) näitab oma uurimuses, et Lance Armstrongi dopinguskandaali kommenteerivad humoorikad Twitteri-säutsud olid populaarsemad ja pikaealisemad kui teised, tõsimeelsed Twitteri-kommentaarid. Tema andmetel jagati naljaga vürtsitatud säutse (nt "Ärkasin täna üles ja mõistsin, et mul on sama palju Tour de France'i võite kui Lance Armstrongil. Ja kaks korda rohkem mune" TED, 10. aprill 2013) rohkem kui mittenaljakaid, seega laiendab humoorikus sõnumite levikut. Kohalikud ja üleilmsed spordimeemid on rahvusliku ja rühmaidentiteedi 
konstrueerimise viis, mille kaudu ühest küljest toetatakse sportlasi, kuid teisalt väljendatakse vastuseisu nende moraalitutele tegudele.

\section{Aines, uurimismeetodid ja analüüs}

Käesoleva uurimuse allikmaterjal on kogutud aastatel 2012-2019 nii inglis- kui ka eestikeelsetest sotsiaalmeediapostitustest ja huumorilehtedelt - suurtest dünaamilistest visuaalse ja verbaalse huumori hoidlatest ( $\mathrm{nn}$ humour hubs), mida kasutatakse aktiivselt ja mis seetõttu osalevad jagatud veebipõhises rahvaluule loome- ja levikuprotsessis (Shifman 2007: 188). Materjal sisaldab nii teksti- kui ka pildiandmeid ning koosneb kahest juhtumipõhisest andmekogumist koos asjakohaste metaandmetega (postituse kuupäev, asukoht, saatja jne). Lance Armstrongiga seotud meemid (kokku 200 üksust) on peamiselt inglise keeles ja Veerpalu/Tammjärve meemid (kokku 60 üksust) on peamiselt eesti keeles. Andmeid säilitatakse Eesti Kirjandusmuuseumi folkloristika osakonna teadusarhiivis EFITA. Metaandmed on kodeeritud kahes järgus, liigitussüsteemi testiti kõigepealt kummastki andmekogust 20 meemi peal ning seejärel kategoriseeriti kogu materjal. Kategoriseerimisel määrati huumori tüüp ja selle loogiline mehhanism (vt Attardo 1994; Attardo \& Hempelmann \& Di Maio 2002), samuti läksid kodeerimisel arvesse huumorisse põimitud globaalsed / kohalikud elemendid. Järgmise tasandi analüüsis tugineti folkloristlikule võrdlusele. Kultuurisemiootilist tõlget ja selle performatiivset konteksti uuriti kvalitatiivselt, et tuvastada meemide levikut toetavaid huumorimehhanisme.

Järgnevalt esitame kahe juhtumi üksikasjalikuma ülevaate - analüüsides 2019. aastal Eesti suusatajate vahistamisega seoses lahvatanud kohaliku juhtumi andmeid, on taustal Lance Armstrongi 2012. aastal laialt tuntuks saanud ja üleilmselt kommenteeritud dopinguskandaal. Toome välja kahe spordiskandaali memeetiliste reaktsioonide populaarsemad teemad.

Seitsmekordse Tour de France’i võitja Lance Armstrongi tiitlid tühistas Rahvusvaheline Jalgratturite Liit 2012. aastal USA dopinguagentuuri aruande põhjal, mis sisaldas 26 tunnistaja ütlusi ja muid tõendeid tema dopingutarvitamise kohta. Talle määrati eluaegne võistluskeeld. Fännide ja laiema avalikkuse šokk väljendus erinevates kanalites, sh meemides, visuaalses ja tekstilises huumoris (nt loodi spetsiaalsed huumori veebilehed, nt https://upjoke.com/lance-armstrong-naljad). Järgnesid ka arvukad visuaalsed humoorikad reaktsioonid.

Veredopingu skandaal eesti suusatajatega tekitas paljuski samalaadset materjali. Murdmaasuusatamine on Eestis olnud aastakümneid väga suure harrastajaskonna ja publikuhuviga spordiala ning seda on peetud eesti rah- 
vusliku identiteedi ehituskiviks (vt ka Voolaid 2017). Dopinguskandaal vapustas spordisõpru pärast 27. veebruaril 2019 Seefeldis toimuvatel Põhjamaade suusatamise maailmameistrivõistlustel korraldatud politseioperatsiooni Aadrilaskmine (sks k Aderlass), millega sooviti paljastada Erfurtis asuva Saksa arsti Mark Schmidti juhitud dopinguvõrgustik. Mitmete spordialade esindajad tunnistasid, et olid Schmidti kliendid ja neile tehti sooritusvõime parandamiseks ebaseaduslik vereülekanne. Operatsiooni käigus arreteeris Austria politsei viis murdmaasuusatajat. Nendeks olid Max Hauke ja Dominik Baldauf Austriast, Aleksei Poltaranin Kasahstanist ning Karel Tammjärv ja Andreas Veerpalu Eestist. Vahistati ka arst Mark Schmidt. Leiti 40 verekotti ja DNA abil tuvastati arsti teenuseid kasutanud sportlased. Tammjärv ja Veerpalu vabastati 28. veebruaril, kui nad olid oma süüd tunnistanud.

1. märtsil 2019 toimunud Eesti ajakirjanike pressikonverentsile ilmus ainult Tammjärv, kes tunnistas veredopingu kasutamist alates 2016. aastast ehk pärast seda, kui Eesti suusatajate endine peatreener Mati Alaver andis talle Austria arsti kontakti. Teine suusataja Andreas Veerpalu lahkus kohe pärast vabanemist ega ilmunud ei pressikonverentsile ega ka hiljem avalikkuse ette. Selline põgenemine ja vaikimine oli vesi meemimeistrite veskile. Meeme hakati tegema nii Andreas Veerpalu kui ka tema isa Andruse kohta, sest juhtum seostati otsekohe Andrus Veerpalu 2011. aasta aprillis aset leidnud dopinguskandaaliga, mis lõppes 2013. aastal õigeksmõistva kohtuotsusega (vt 2011. aasta dopinguskandaali folkloorsete reaktsioonide kohta Voolaid \& Laineste 2013; Voolaid 2014). Paljud meemid kommenteerisid isa ja poeg Veerpalu (ja paljude teiste tuntud Eesti suusatajate) käitumist. Samuti pilgati Mati Alaveri, kelle Harju maakohus mõistis 14. novembril 2019 kokkuleppemenetluses dopingu tarvitamisele kallutamises süüdi ning karistas teda aastase tingimisi vangistusega poolteiseaastase katseajaga. Alaver jäi ilma ka riiklikest tunnustustest, Eesti president Kersti Kaljulaid võttis temalt ära kaks riiklikku teenetemärki, Eesti Olümpiakomitee treenerite kutsekomisjon tühistas Alaveri kutsetunnistuse.

Nende sündmuste ajel reageeris üldsus teksti-ja pildimeemide, vanasõnade ja vanasõnamodifikatsioonide, mitmesuguste naljadega. Esimesed folkloorsed kajastused ilmusid veebis leiduvate uudistesaitide artiklikommentaarides. Kommentaarides kasutatav sagedane vanasõna oli "Käbi ei kuku kännust kaugele". See osutas otsesõnu Veerpalude dünastiale ja võimalikule seosele varasema ja käimasoleva dopingujuhtumi vahel. Ehkki 2013. aastal sai Andrus Veerpalu juhtum tõendite puudumise tõttu kohtuvõidu, mis pani spordipubliku ja laiema avalikkuse toona rõõmustama, tõi uus juhtum kahtlusepilved taas olümpiavõitja kohale ja 2011. aasta juhtumiga seoses hakati rääkima võimalikust pettusest (vt ka pettustega seotud meemid, joonised 1 ja 12). 
Isa ja poja suhtele viitasid kohe ka esimesed tekkinud meemid, mis omakorda põhinesid keelenaljal, täpsemalt homonüümiat kasutaval kalambuursel keelenaljal. Näitena sobib siia meem, millel isa Andrest kujutatakse poja toas treeningut seiramas ja küsimas: “Andreas, dopingut ikka paned?" Vastuses "Muidugi Andrus, see on mul veres" on sõna "veri" kahetähenduslikus funktsioonis, nali tekib "vere" kui sugulussideme plaani sissetoomisel, homonüümikonfliktist põhjustatud mõistmistõrkel (vt joonis 1).

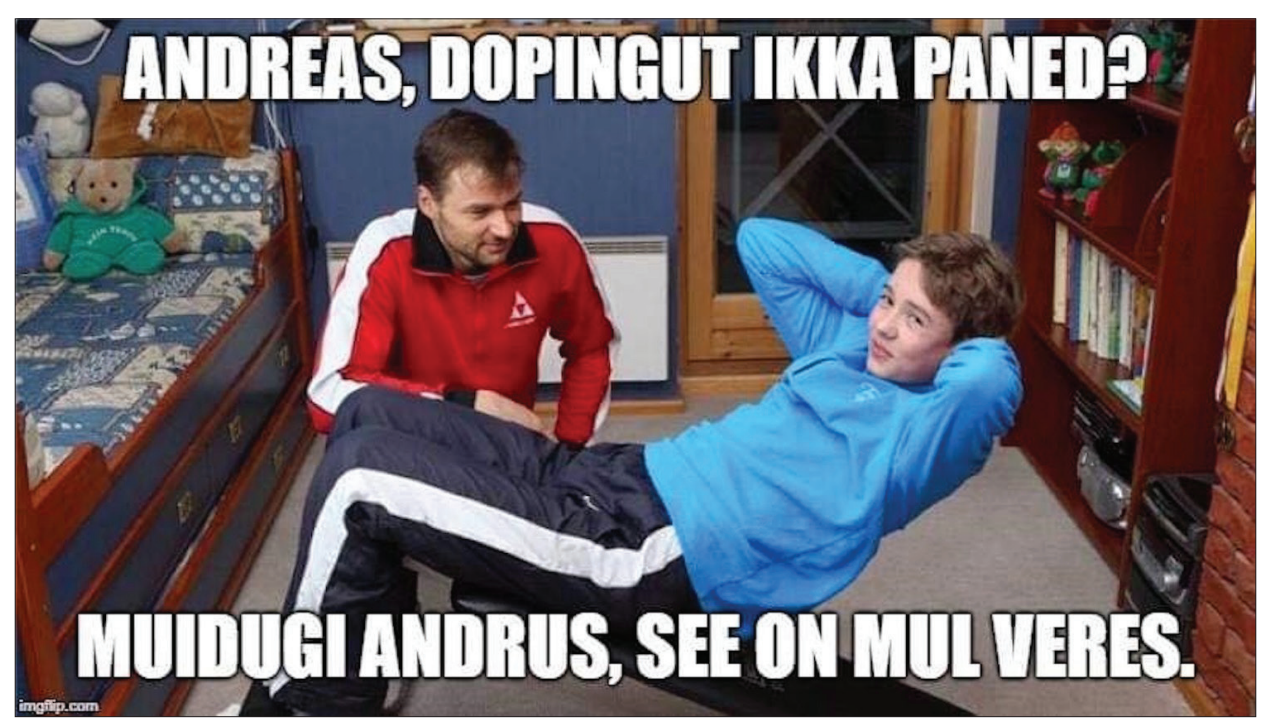

Joonis 1. EFITA F02-015-0001.

Uue skandaali valguses omandas varasemates meediaartiklites positiivsena mainitud Veerpalude veresugulus (poeg soovib olümpiasangarist isa jälgedes käia, vt joonis 2a) täiesti uue tähenduse. Toonast tõsist artiklit jagati nüüd uues olukorras iroonilise tähendusvarjundiga.

Keeleliselt tõusiski ühe olulise huumorimehhanismina esile mäng sõnaga "veri" ja sellega kombineerituna (rohkem ja vähem juhuslikud) paronüümsed/ homonüümsed tähendusväljad. Veredopingu tarvitamine seostati mitmete rahvusvaheliselt tuntud popkultuuri elementidega, nt levis filmi "Verevennad" reklaamplakat (joonis 3), mis kuulutas, et juhtum põhineb tõsielul ja peategelasi kehastavad näitlejad Andreas Veerpalu ja Karel Tammjärv. 
Andreas Veerpalu loodab isa jälgedes käia

Maarja Värv
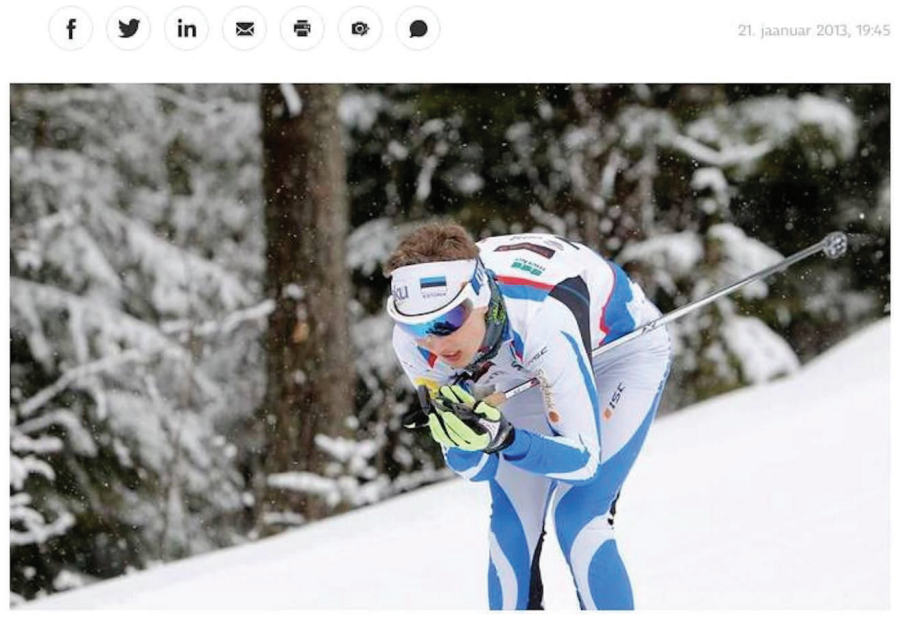

Andreas Veerpalu

FОTO: Tairo Lutter / Õhtuleht

Joonis 2a. Artiklist "Värv" 2013. EFITA F02-015-0002.

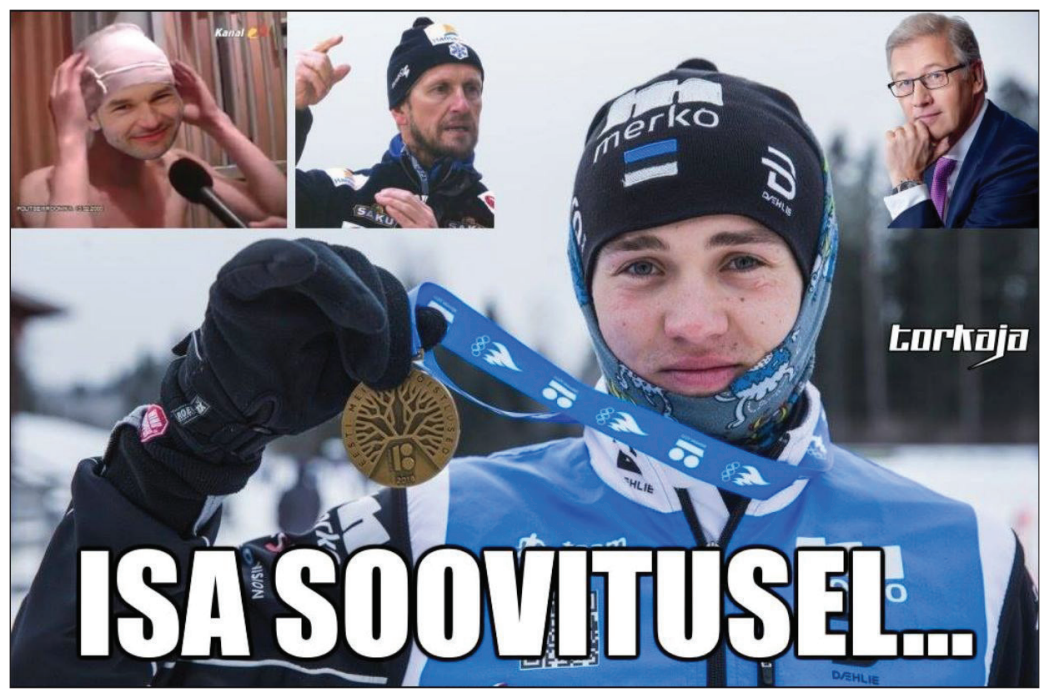

Joonis 2b. EFITA F02-015-0021. 


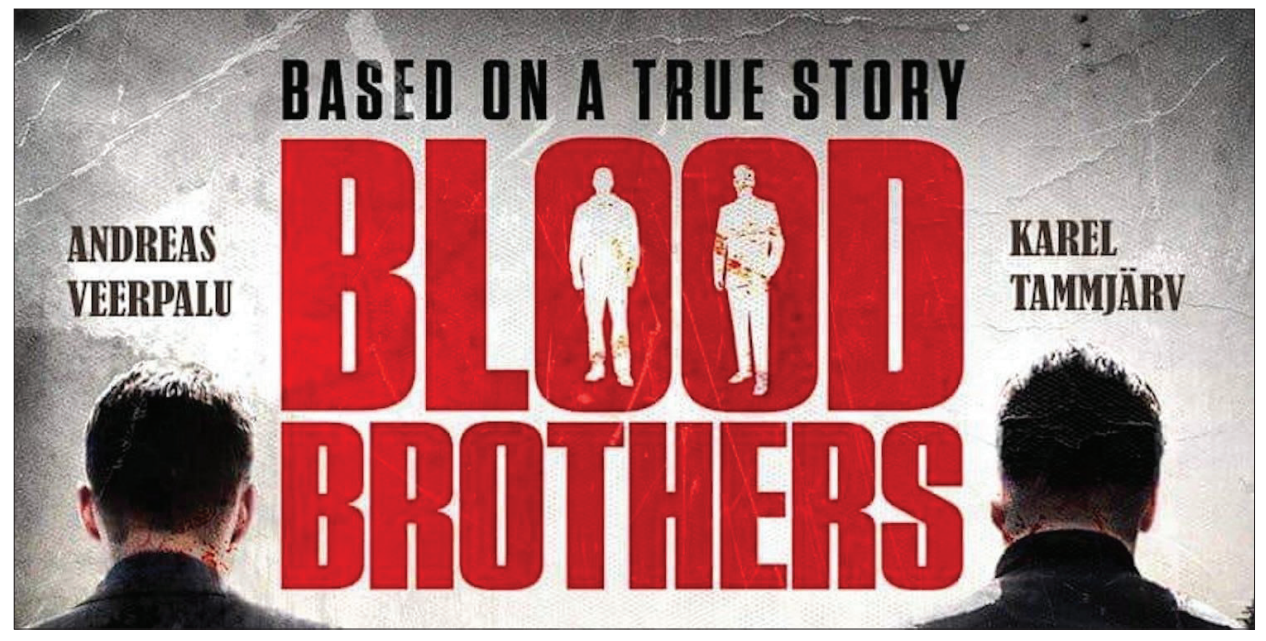

Joonis 3. Põhineb tõsielusündmustel. "Verevennad". Meemi aluseks on filmi "Verevennad" reklaamplakat. EFITA F02-015-0006.

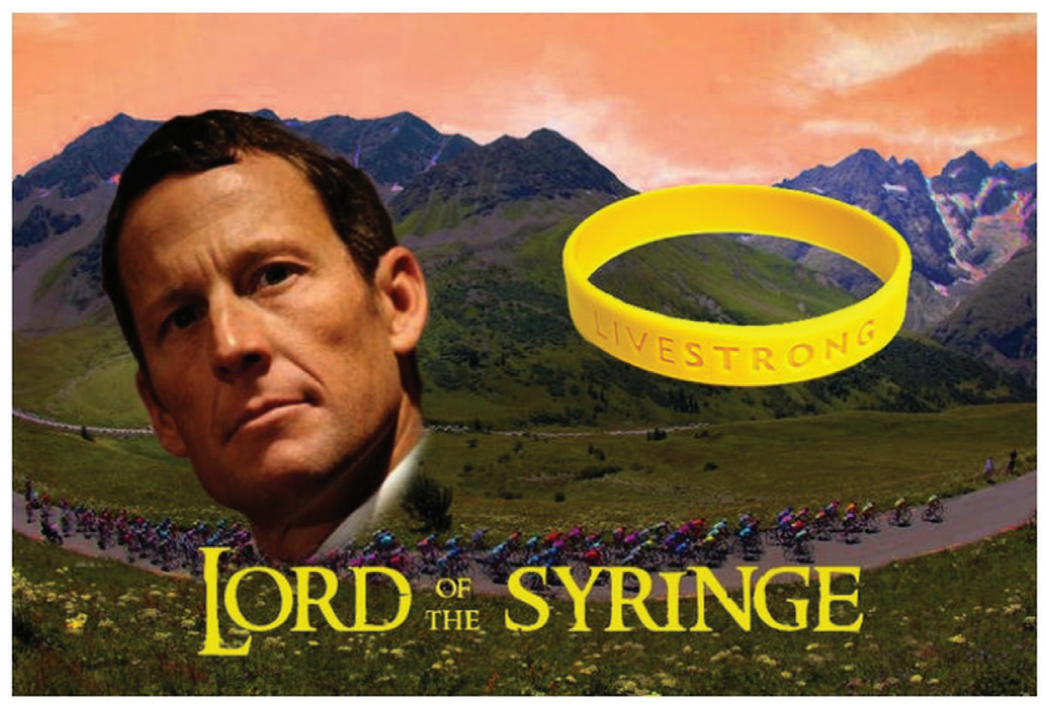

Joonis 4. Filmi "Sõrmuste isand" paroodiaplakat "Süstla isand". EFITA F02-015-0048.

Täpselt sama võtet oli rakendatud Armstrongi juhtumi ajal, kui parodeeriti popkultuurimotiivina filmi "Sõrmuste isand" plakatit uue teemakohase filmipealkirjaga "Süstla isand" (joonis 4). 
Varasemaid kultuuritekste modifitseerides toetuvad internetikasutajad jagatud glokaalsele (Robertson 1995) kultuuripagasile, tekstiressurssidele mingi kogukonna (siinjuhul eestlaste) kollektiivses mälus (vt ka Wertsch 2002: 120). Kohandatavate motiivide allikaks saavad nii suuline pärimuskultuur kui ka koolilugemus, kohustuslik kirjandus ja õpikud ning kõnealuste dopingujuhtumi meemide näitel ka muusika (laulusõnad), filmikunst, reklaam ja massimeedia.

Materjalis näeme, et sageli on huumori allikaks homonüümsed lekseemid ehk erilekseemid, mille osa vorme või kõik vormid langevad kokku. Eestikeelne sõna "veredoping" iseenesest pakub selle võimaluse, juhuslikult haakuvad ka sportlase nimi Veerpalu ja treeneri nimi Alaver (mõlemas osalekseem ver-) homonüümselt ja pakuvad loomingulistele meemimeistritele mitmeid sõnamängulisi võimalusi, nt Eesti sporti ei aita isegi Alavere vahetus ja A la verikäkk (EFITA F02-015-0045). Mõistega "veri” seotud osalekseeme paigutati väga erinevatesse kultuuriseostesse, sageli esineb viiteid varasematele kultuuritekstidele ja/või parodeeritakse neid. Nt tekkis lauluparoodia Virve Köstri (üldsusele tuntud Kihnu Virve) laulust "Merepidu" just sobiva tekstuuri tõttu. Refräänis "Meri on, meri jääb, meri olema peab" oli väga lihtne asendada sõna "meri" riimuva vastega "veri" (joonis 5). Analoogselt on parodeeritud Gennadi Podelski omaaegset hitti "Suusabaasis on tantsupidu" sõnadega "Suusabaasis on verepidu! See toimub siin igal õhtul” (joonis 6). Siin peitub ühenduspunkt situatsiooni sarnasuses - suusatajate treeninglaagris. Sellised keelenaljad on tõlkimatud, kuid ühine element ja intertekstuaalne kohanemisprotsess puudutab mehhanis-

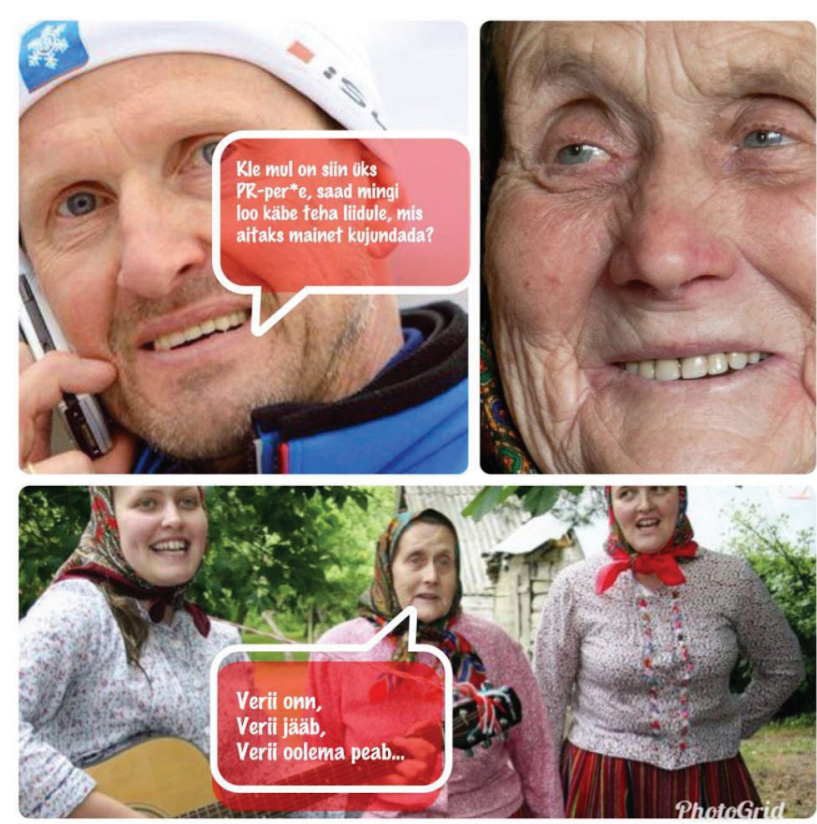
mi ennast. Skandaalide reaktsioonina loodud meemides on tavaline, et mitmesugused sõnamängud on toimunu kommenteerimiseks esmased vahendid (Kuipers 2005).

Joonis 5. Mati Alaver ja Kihnu Virve. EFITA F02.

015-0011. 


\section{Suusabaasis on verepidu! See toimub siin igal õhtul ...}

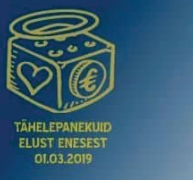

Joonis 6. EFITA F02-015-0004.

Armstrongi juhtumis osutus selliseks kultuuriliseks ressursiks näiteks Nike’i reklaamist tuntud loosung "Just do it" (joonis 7).

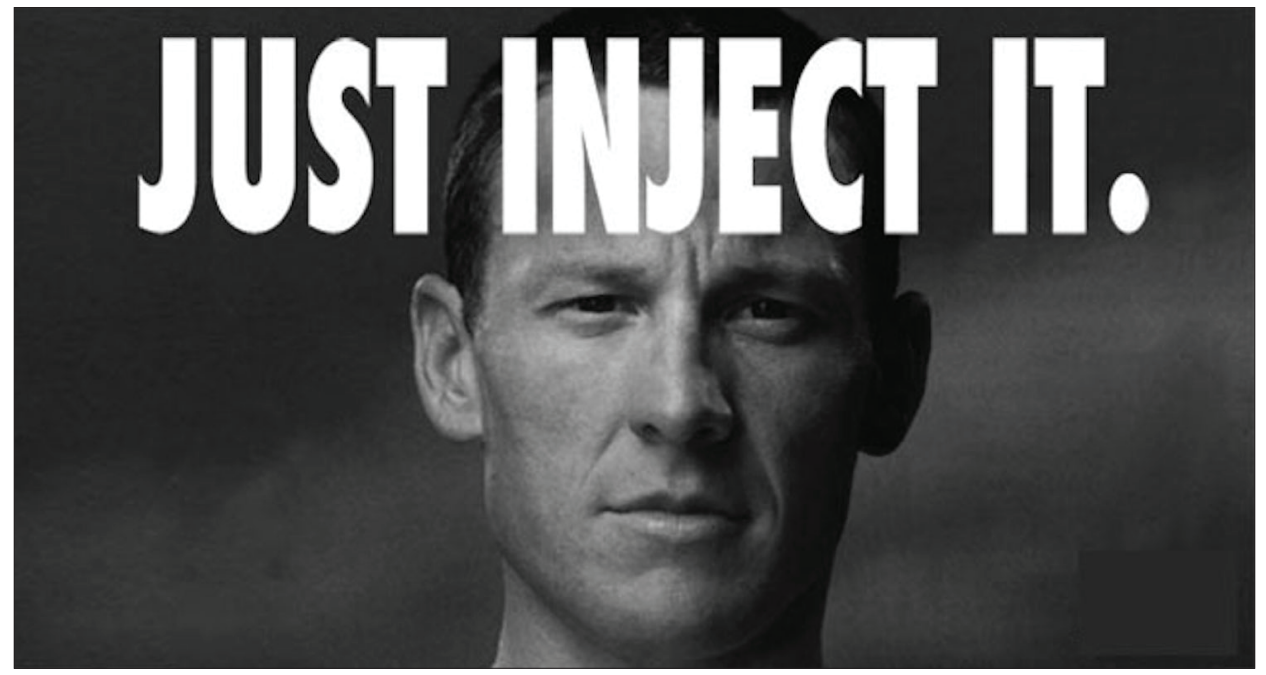

Joonis 7. Lihtsalt süsti seda (firma Nike slogani "Just do it” paroodia). EFITA F02-015-01-0045. 
Armstrongi puudutavas materjalis loodi seosed ka tema kuulsa nimekaimu, astronaudi Neil Armstrongiga. Kahe nime sisuliseks sidumiseks viidati mõningates ringkondades levinud kahtlusele, kas üldse Kuul käidi (joonis 8): kuigi Kuul tehti palju fotosid, polnud Neil Armstrong neist ühelgi ja pidi seetõttu hiljem valetamissüüdistuste vastu võitlema. Jalgrattur Lance Armstrong seevastu eitas dopingusüüdistusi (nt 2005. aastal ütles ta: "Ma pole kunagi dopingut pruukinud. Ma võin seda uuesti öelda, aga olen seda öelnud juba seitse aastat.” King 2005).

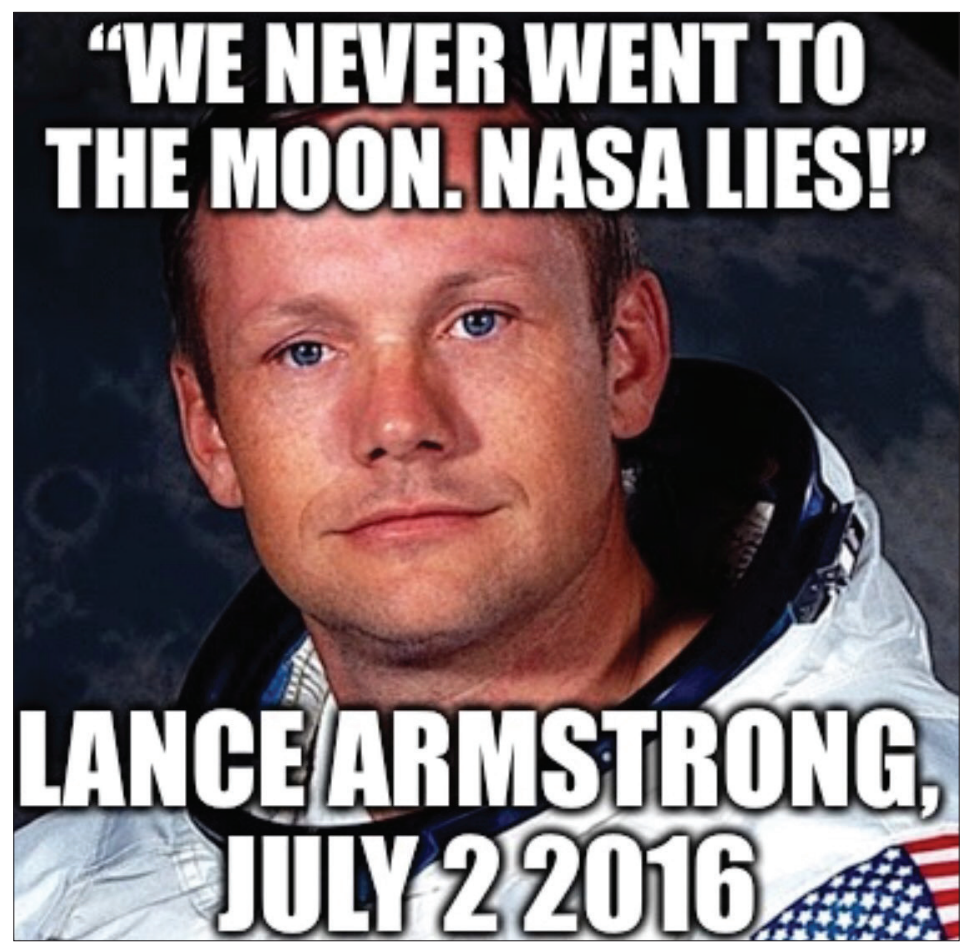

Joonis 8. Me ei käinudki Kuu peal. NASA valetab! Lance Armstrong, 2. juuli 2016. EFITA F02-015-01-0029.

Armstrongi juhtumis kasutati allikmallina ka mitmeid rahvusvaheliselt tuntud kultuuritekste. Populaarne oli nt tuntud meemimall "Hitler on maruvihane" ("Hitler rant", vt Know Your Meme) pealkirjaga "Hitler Reacts to Lance Armstrong Admitting to Doping" ("Hitler reageerib Lance Armstrongi dopingu ülestunnistusele”, https://www.youtube.com/watch?v=MP6QgAoxb3Q). 
Sarnase dopinguteemalistele sõnamängudele baasmaterjali pakkunud kultuurilise ressursi moodustasid eespool nimetatud vanasõnad. Varasemaid vanasõnu kohandati dopinguskandaaliga, näiteks levis vanasõnaparoodia "Vaikimine Veerpalu, rääkimine Pilv" (vanasõna "Vaikimine hõbe, rääkimine kuld" eeskujul) - viidates tõsiasjale, et isa Andrus Veerpalu üritas varasemate süüdistustega hakkama saada vaikides, samal ajal kui tema advokaat Aivar Pilv võttis olümpiavõitja sõna otseses mõttes puhtaksrääkimise enda kanda (EFITA F02-015-0045). Vanasõna "Kui pea ei võta, siis võtavad jalad" sai aga meemimeistritelt edasiarenduse "Kui jalad ei võta, siis tuleb verd võtta" (joonis 9). Meemil on kujutatud Austria suusataja Max Hauke, kes arreteeriti koos eestlastega veredopingu kahtluse tõttu. Operatsiooni Aadrilaskmine käigus tehtud pildi lekitas politseinik, ja see foto kujunes skandaalis sümbolväärtusega malliks, mida meemitegijad laialdaselt kasutasid.

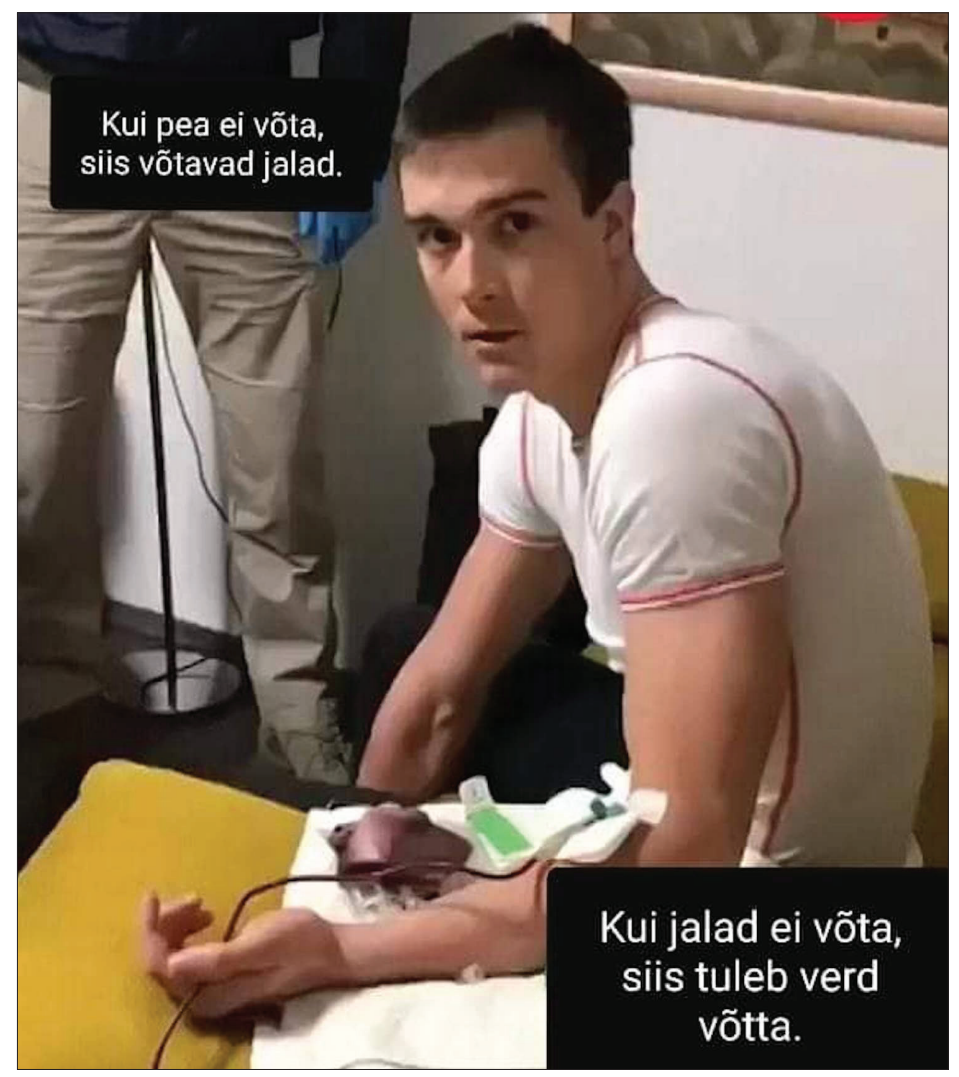

Joonis 9. EFITA F02-015-0009. 
Väärib mainimist, et Armstrongi juhtumis olid sellised homonüümsed kalambuurid samuti olemas. Osalekseem arm- võimaldas taas loominguliselt kalambuure luua, tulemuseks ingliskeelsed armstrong ja armweak ('tugev käsi' ja 'nõrk käsi') (joonised 10a ja 10b).
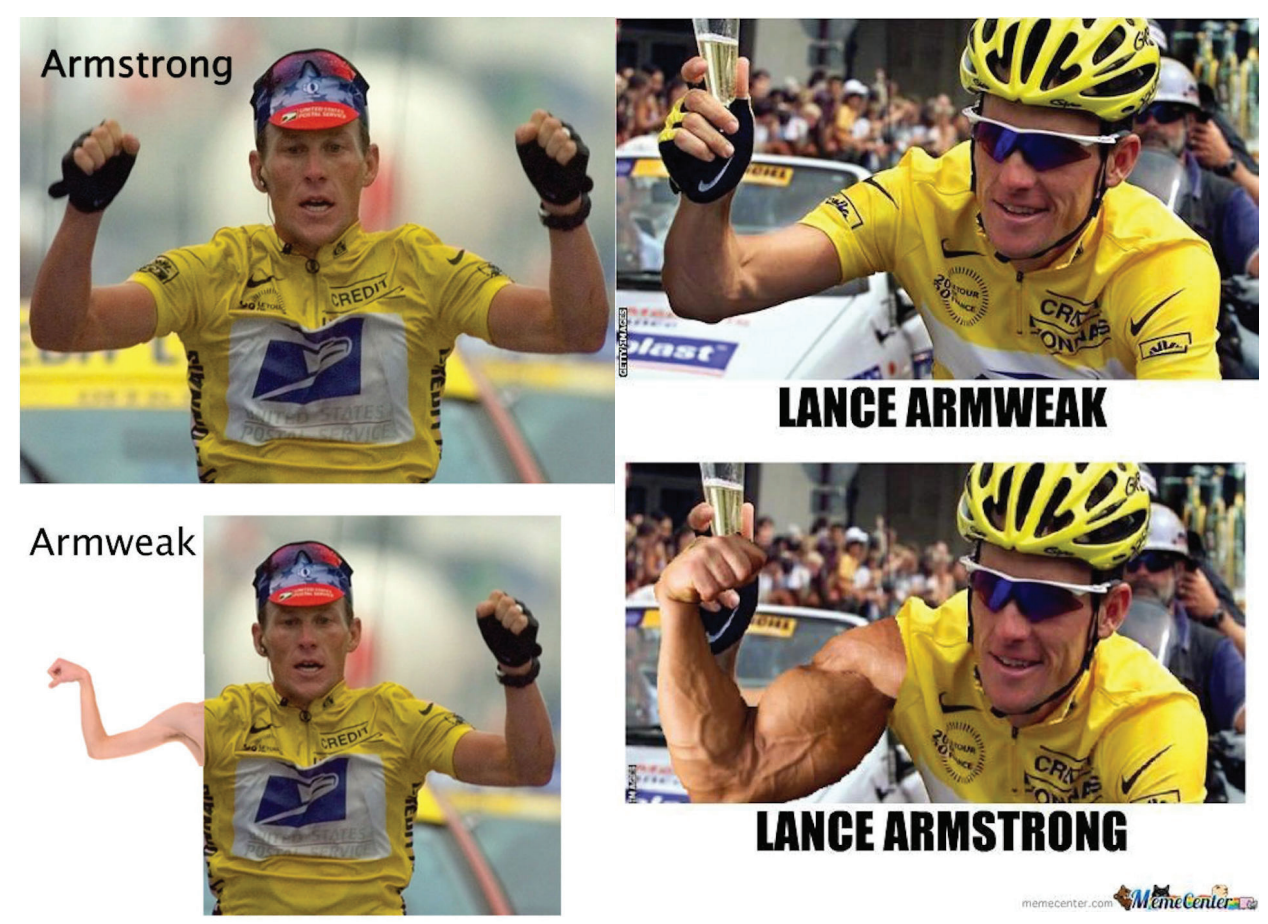

\section{LANGE ARMWEAK}

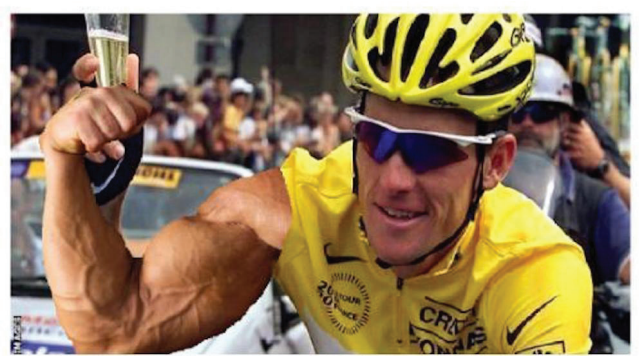

\section{LANGE ARMSTRONG}

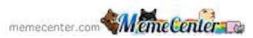

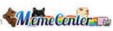

Joonised 10a ja 10b. Armstrong/armweak; Lance Armweak / Lance Armstrong. EFITA F02-015-010023, EFITA F02-015-01-0046.

Universaalse ühisosana saab välja tuua mõlemas juhtumis levinud homonüümikonfliktil põhineva nalja, kus keskseks on mõiste "positiivne" (joonised 11 ja 12). 2019. aasta Eesti juhtumis seostati see motiiv 2011. aasta aprillis lahvatanud Andrus Veerpalu dopingujuhtumiga (joonisel 12 toonane pressikonverents, mis juhtumi päevavalgele tõi). See näitab, kuidas vanad juhtumid uues naljaraamistuses taas aktuaalseks muudetakse. 
Joonis 11. Parim meetod spordis õnnestuda on jä̈̈da positiveseks - Lance Armstrong. EFITA F02015-01-0043.

Joonis 12. Telesaate "Rooside sõda" juht Kristjan Jõekalda esitamas küsimust: "Nimeta üks positiivne asi" - allpool toodud foto Mati Alaveri ja Andrus Veerpalu pressikonverentsist viitab otseselt positiivsele dopinguproovile. EFITA F02-015-0024.

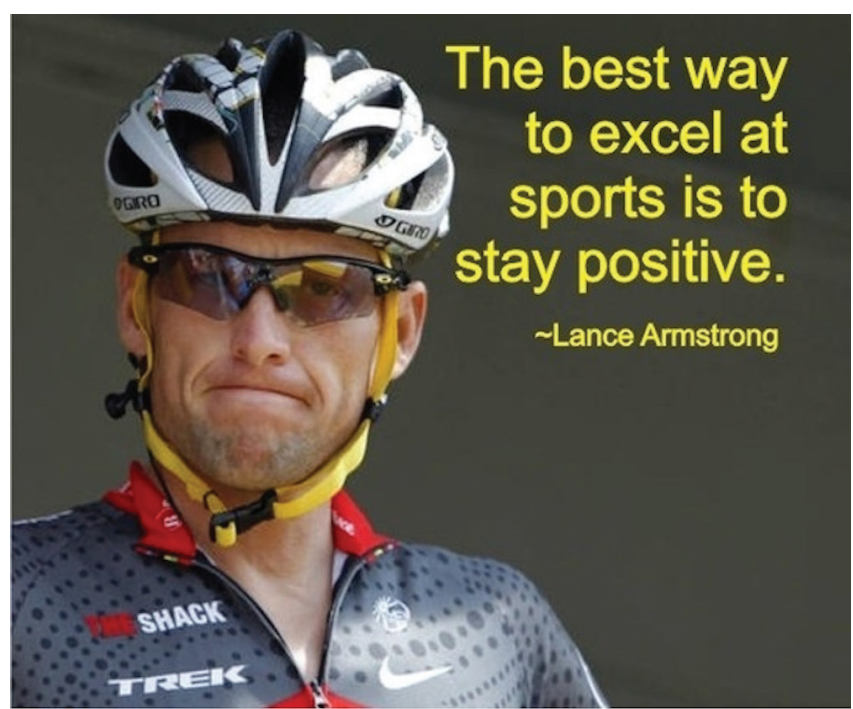

See More Crazy Pictures \& Videos on Owned.com

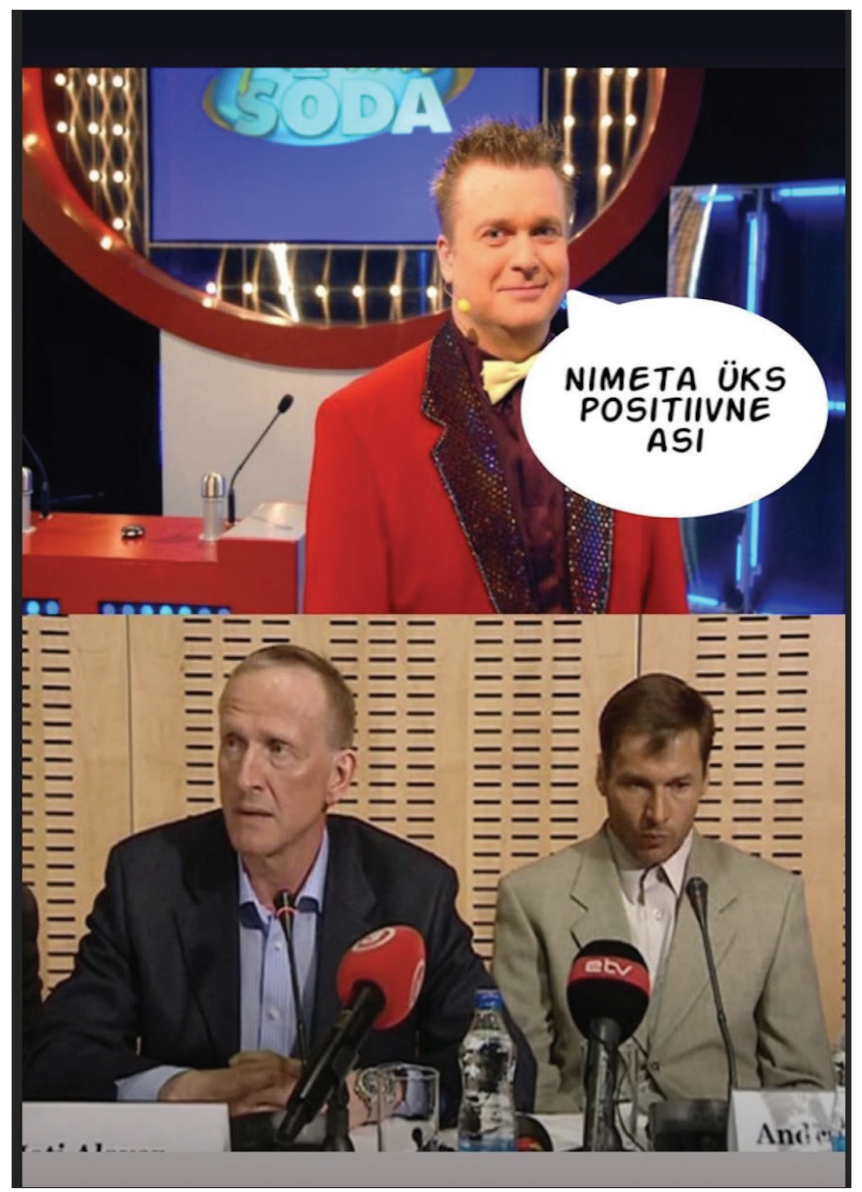


Mõlemal juhul mängiti meemides kontrastiga/sarnasusega spordikuulsuse ja tavainimese vahel. Armstrongi kaotatud võidud võrdsustasid ta tavainimese, st mittesportlasega. Eesti 2019. aasta juhtumis andis huumorile lisatasandi asjaolu, et ükski noortest suusatajatest polnud dopingutarvitamisele vaatamata spordis märkimisväärset tulemust saavutanud. Iga tavainimene on justkui parem kui patustanud sportlane: sporditulemused on samad, kuid boonuseks on neil puhas südametunnistus (joonised 13 ja 14).
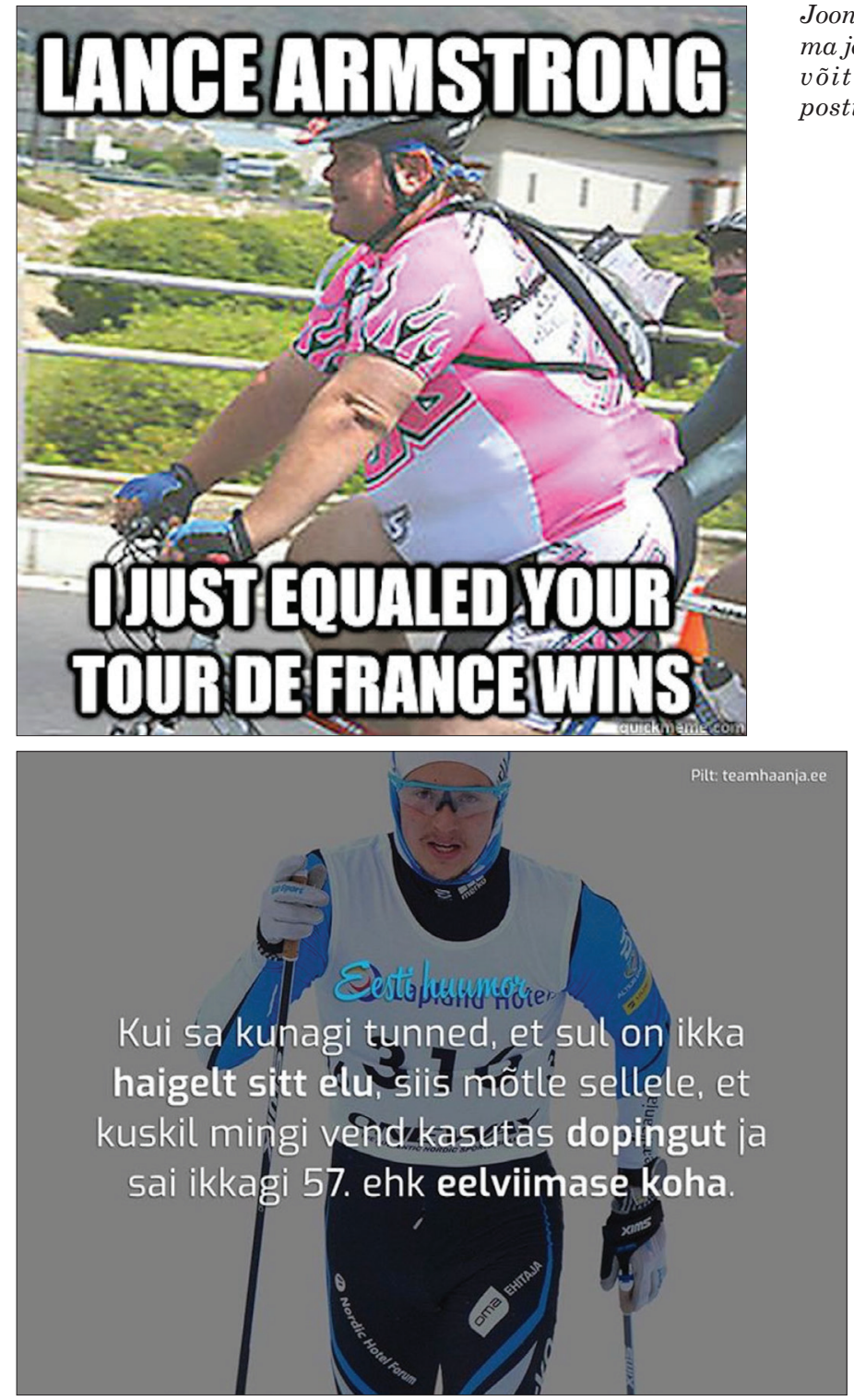

Joonis 13. "Lance Armstrong, ma jõudsin su Tour de France'i võitudega samale verstapostile”. EFITA F02-015-01-

0009 . 
Eriti huviväärne on nalja tõlke seisukohast meem, mis seletab eesti suusatajate viletsaid tulemusi sportlaste sooviga dopingupatusena mitte kahtlust äratada (joonised 15a ja 15b). Nimelt levis see koomiksi laadis nali ka ümberpanduna võru keelde, ning murdes esitamine lisas naljale veel ühe intertekstuaalse kihi. Aimatav on vihje Lõuna-Eestile kui tuntud murdmaasuusatamise piirkonnale, Veerpalu ja Tammjärv olid just selles piirkonnas registreeritud Team Haanja liikmed.

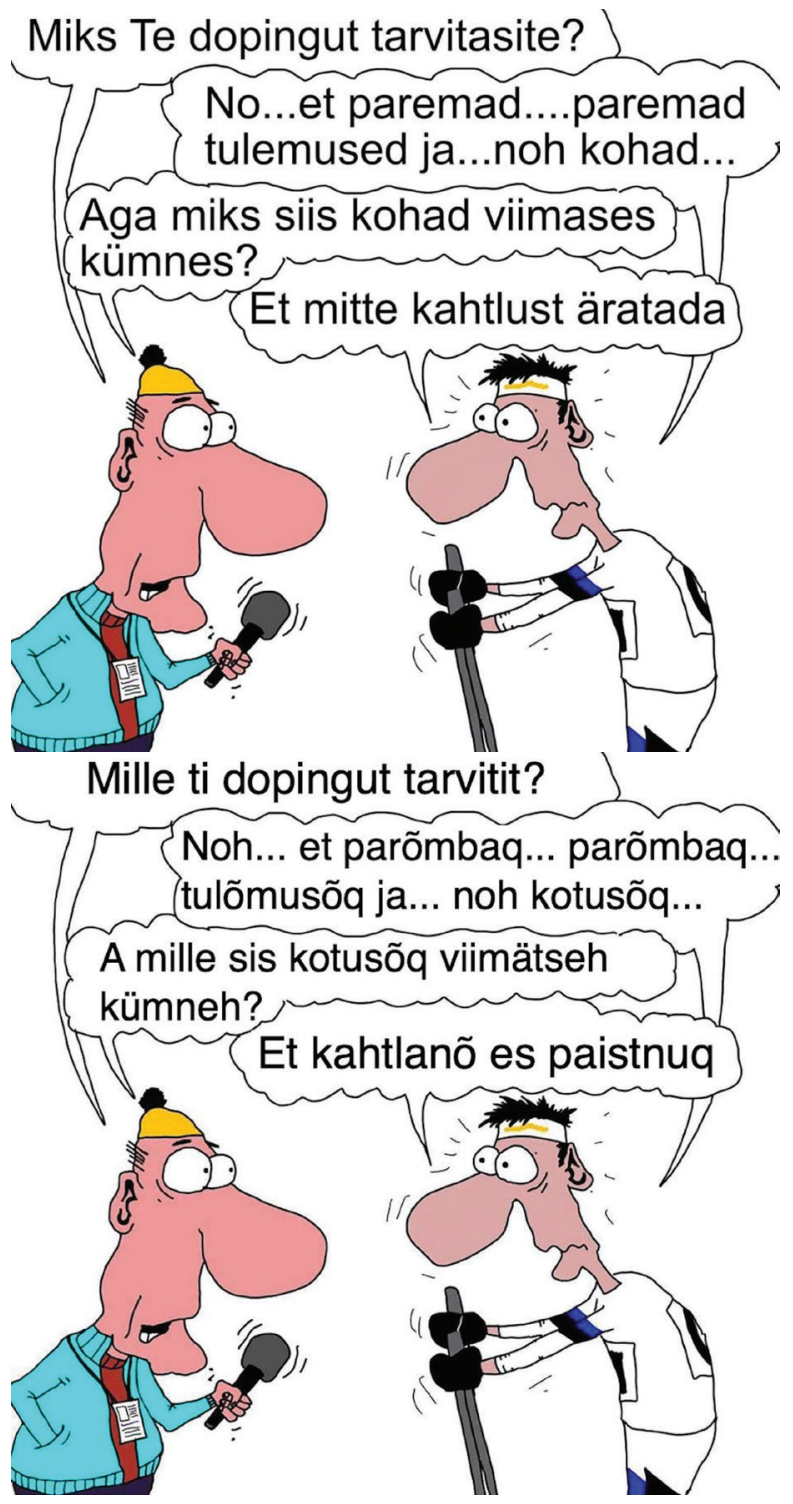


Dopingujuhtumi meemides võidakse teemaga seostada ka muid parasjagu ühiskonnas käimasolevaid skandaale ja aktuaalseid arutelusid, nt järgnev meem segab teemasse Tallinna Ülikoolis bakalaureuse kraadi kaitsnud Eesti poliitiku Rainer Vakra plagiaadiskandaali, mis esitati meemis vastava kõnekäänulise võrdlusega: "Nagu kaks tilka verd" (joonis 16). Kaht juhtumit ühendavaks elemendiks on nalja sihtmärgi silmakirjalikkus, pettus ja valemäng. Meem levis nädalalehes Eesti Ekspress avaldatud rubriigis "Nagu kaks tilka vett" (antud juhul: verd), milles võrreldakse inimeste fotosid ja vahetatakse fotode allkirjades inimeste nimed.

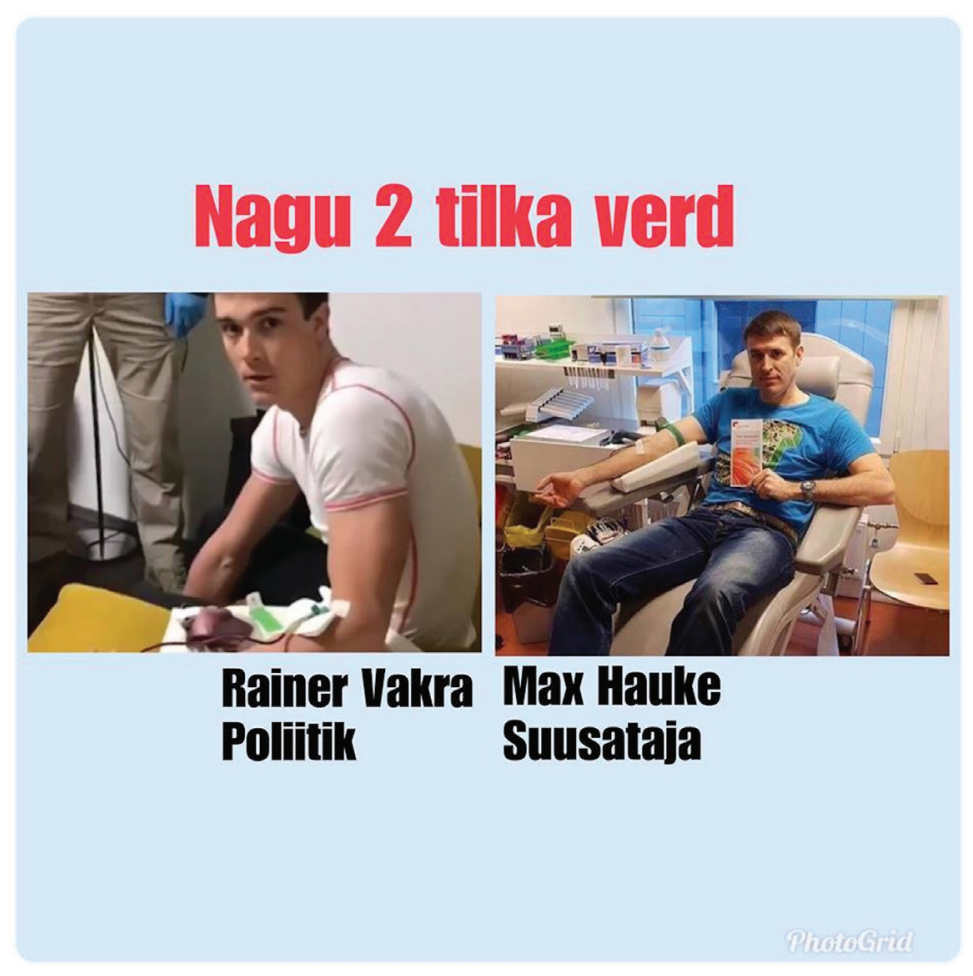

Joonis 16. EFITA F02-015-0008.

Üks osa meeme on üles ehitatud ka keelatud ainete pruukimise õigustamisele. Varasemate dopingujuhtumite analüüsimisel on selgunud üldsusele üldomane stereotüüp, et puhast sporti pole olemas, kõik sportlased tarvitavad keelatud aineid (vt ka Voolaid \& Laineste 2013: 25). Meemideski väljendub sama idee (joonis 17). 
Joonis 17. "Oot, kui kõik dopingut tarvitavad - kas see ei tee teda siis ikkagi kõigi aegade parimaks?” EFITA F02015-01-0007.

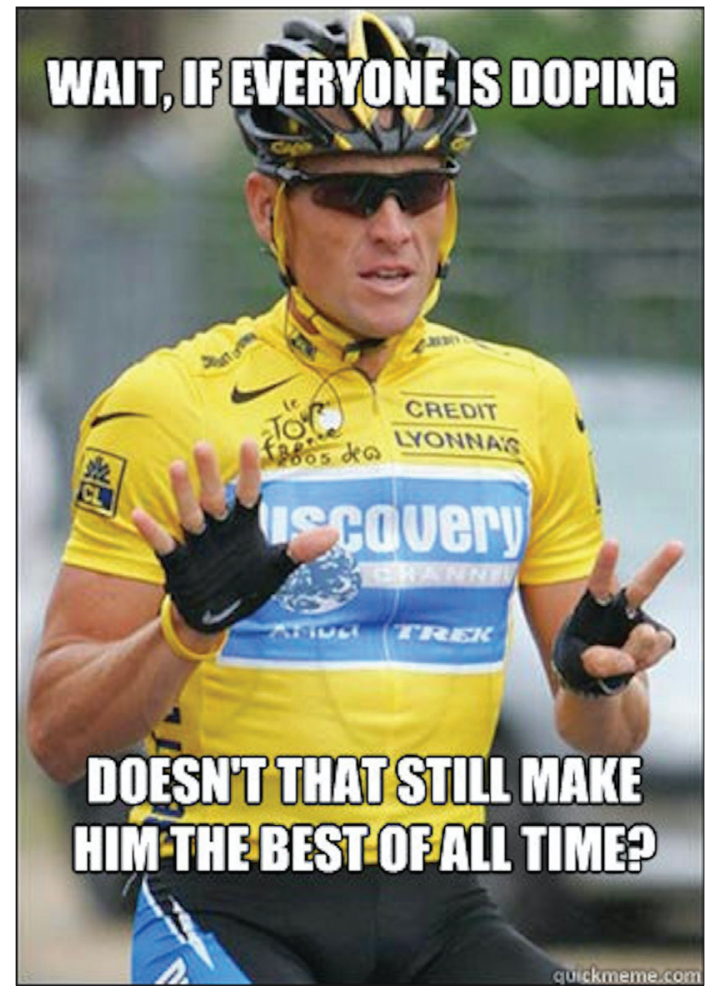

Kahe käsitletud dopingujuhtumi võrdluses ilmneb mastaapide ja kontekstilise tausta erinevus. Lance Armstrongi peeti üheks kõigi aegade suurimaks sportlaseks, kes tegeles ka heategevusega, et aidata omanimelise sihtasutuse kaudu miljonitel vähiga võidelda; ta oli võitude ja heategevuse poolest tuntud kangelane. 2019. aastal arreteeritud Eesti suusatajad olid riiklikult ja rahvuslikult tähtsa spordiala esindajad ja seega mõjutasid nende väärteod rahvuslikku uhkust ja rahvuslikku identiteeti, kuid nende juhtum ise oli rahvusvaheliselt palju pisema kaaluga, nagu ka nende sportlikud saavutused.

Järgnevalt esitame peamised järeldused, mis puudutavad kahe juhtumi teemalisi meeme ja nende konteksti põimitud üldisemaid stereotüüpe, ideid ja malle ning toome välja huumorimehhanismid, mida kasutatakse meemide loomisel ja nende kultuurisemiootilises tõlkes. Analüüs heidab valgust meemide loomise ja jagamise loogikale globaalses ja lokaalses kontekstis ning näitab, kuidas meemid käsitlevad globaliseerumise ja lokaliseerimise vahelisi pingeid.

Nii nagu kogu folkloorile, on ka meemidele omane korratavus (vt Leavitt 2013; Shifman 2014). Et näidata, kuidas kohanemisprotsess meemides töötab, juhime tähelepanu kahe andmekogu sarnasusele. Meemides väljendub see peamiselt 
spordiskandaalide käsitlemise üldises mustris. Dopingujuhtumid on üldarusaadavad, sest põhinevad tüüpilistel olukordadel ja isikutel (dopingut tarvitavad tuntud sportlased, ained on enamasti samad, sport on universaalne nähtus ja spordil on pealtvaatajad, kes jagavad veendumusi ja hoiakuid spordi, dopingu jms kohta) ning need elemendid moodustavad avalikkuse reaktsiooni alustala. Ükskõik kas teksti- või pilditasandil leiab iga spetsiifilises keelelis-kultuurilises keskkonnas tegutseja oma kontekstile sobiva lähenemisviisi, kuid põhiloogika on kultuuride ja keelte lõikes sarnane. Pildiliselt on universaalne näiteks meditsiinivarustuse kujutamine (joonis 16) või kangelaste demüstifitseerimine (joonised 13, 14). Sõnalises pooles kasutatakse universaalseid malle oluliselt harvemini. Otsetõlge on väga haruldane ja piirdub juhtudega, kus sõnade väliskujul (nt "positiivne") on originaal- ja sihtkeeles kattuv sisuline tähendus ja sõnu saab neis keeltes kasutada sarnasel viisil. Tõlkimatuse põhjustena võib välja tuua piiratud juurdepääsu kultuurilistele tekstiressurssidele (nt joonised 5 ja 6) ning tekstilise eripära (huumori allikaks olevad homonüümsed ja paronüümsed kokkupõrked ehk tekstuur, vt Dundes 1964). Seega, ehkki Eesti meemitegijatel oleks olnud hõlpsam kasutada varasemate rahvusvaheliste dopingujuhtumite meeme, muuta ainult pilti (kasutades varasema asemel kohalike sportlaste pilti) ja jätta alles tekst või kasutada üldist meemimalli (joonis 4) ja tõlkida eestikeelne tekst, üldiselt seda ei tehtud. Meemiloojad panustasid selle asemel kohalikule keelelis-kultuurilisele kompetentsile, et luua uusi meeme, ning kasutasid viiteid varasematele või samaaegsetele aktuaalsetele (kohalikele) skandaalidele, kohapeal saadaolevatele piltidele jne. Nende valikuid ajendasid kogukonnaga seotud aspektid (Blank 2016), mis reguleerivad tuntud valemite kohandamist või kultuurisemiootilist tõlget uutesse kasutusümbrustesse, kinnitades seega kogukondlikku kuuluvust ja sidusust. Võib öelda, et kohanemine toimub, kuid ainult üldisel, spordi ja dopingu valdkonnaga seotud tasandil.

Meie lõppeesmärk oli osutada globaalsete ja kohalike narratiivide tähtsusele meemiloomes. Analüüsil selgus, et Armstrongi meemid on globaalsemad ja sisaldavad viiteid, mis on laialt tuntud või vähemalt arusaadavad (nt joonis 8), samal ajal kui eesti meemid on spetsiifilised, kinnistatud konkreetsesse aja- ja kultuuriraami (joonis 16). 2012. aasta Armstrongi meemid võisid anda tõuke meemimallidele, mida 2019. aasta Eesti meemid võtsid seitse aastat hiljem kaudselt eeskujuks (sh osutades, kuidas dopingusüüdistustesse suhtub sporti armastav, kuid dopingut põlgav publik), kuid nende sisu inspireerib siiski tugevasti kohalik taust. Järelikult on globaalse / lokaalse kohanemise keskne idee kohalike vajaduste, ideede ja emotsioonide teenimine (vt ka Shifman 2014; Nissenbaum \& Shifman 2018). 


\section{Kokkuvõtteks}

Meemi ning selle kultuuriliste ja intertekstuaalsete viidete tasandil on huumor - eriti sõnanali - sageli tõlkimatu. Võimalik on siiski kultuurisemiootiline tõlge ehk kohandamine, mis võtab arvesse sihtkeele tähenduse semiootilisi süsteeme. Meie uuringus osutus analüüsitud andmestikus kõige sagedasemaks huumorimehhanismiks sõnamäng. Seega kasutavad meemimeistrid mõlemas juhtumis (ja igas keeleliskultuurilises keskkonnas ehk semiosfääris) huumorimehhanisme, mis annavad sarnaseid/analoogseid, kuid mitte identseid tulemusi.

Sarnased ja erinevad aktuaalsed memeetiliste reaktsioonide kategooriad globaalsed ja kohalikud (Armstrong ja Veerpalu/Tammjärv) - osutavad kahes rahvusvahelises dopingujuhtumis spordieetikale ja meditsiinile. Sarnased stereotüübid ja ideed on seotud sellega, mis puudutab rahvusvaheliselt levinud spordikultuuri: populaarseid ja suure vaatajaskonnaga spordialasid, kuulsuste kultuuri ning üksikisiku ja avalikkuse vahelist pinget. Kate Miltner ja Tim Highfield (2017: 7) viitavad sellele, et kui publikureaktsiooni vormiks on valitud GIF-formaat - failivorming, mis võimaldab kujutisejadade lõputut ringedastust -, eelistatakse vanade mallide taaskasutamist, isegi kui nende asemel oleks võimalik kasutusele võtta miljoneid erinevaid meemimalle. Meie avastasime, et kuigi globaalsete ja lokaalsete assotsiatsioonide keskne suunav loogika kattub, ei saa seda öelda sisu - piltide ja tekstide endi - kohta. Need sõltuvad meemitegijate keelelis-kultuurilistest võimetest ja teadlikkusest ning on pigem kohaliku levikuga. Kohanemise käigus põimuvad üleilmsed ja kohalikud narratiivid; lisaks ühendatakse ja seotakse meemilises reaktsioonis spordiskandaaliga muidki aktuaalseid poliitilisi või avaliku elu päevateemasid, kui see kuulub meemilooja ja/või tema intertekstuaalse kultuurilise "sõnavara" hulka või kui sellega on seotud tema publik. Sellist universaalsete motiivide kohandamist kohalikuks kasutamiseks oleme artiklis vaadelnud kultuuritõlke protsessina (vt ka Voigts 2017; Cannizzaro 2016). Üks olulisi meemide ja meemiteemade kohandamise aluseid on lähteainese semiootiliste assotsiatsioonide mitmekülgsus. Inimesed loovad ja levitavad meeme, kui lähteaineses on elemente, millel on huumoripotentsiaali, (keelelisi, kultuurilisi ja kultuuridevahelisi) intertekstuaalseid komponente, mille "külge" uusi tähendusi haakida, püsiv avalik huvi jne. Need markerid aitavadki ennustada meemide laiaulatuslikku kohandamist ja levikut.

Globaalsetel meemikogudel on rohkem kasutajaid, mistõttu on need ka sisult mitmekesisemad (Gumkowska \& Toczyski 2016: 41). Ingliskeelsed meemid on kättesaadavad märkimisväärselt suuremale hulgale internetikasutajatele, mistõttu peaks olema rohkem varieeruvust ja globaalseid intertekstuaalseid 
viiteid. See tähendaks ühtlasi, et Eesti meemides peaks leiduma vähem intertekstuaalseid viiteid. Meie materjali põhjal võib aga väita, et see oletus ei vasta tegelikkusele: vastupidi, varieerumisaste ja originaalelementide arv oli Eesti allikmaterjalis oodatust suurem (vt ka Börzsei 2013: 20). Tulemus osutab, et meemimehhanismidel on eri keeltes võrdne potentsiaal, sõltumata sellest, kui palju inimesi seda keelt räägib.

Emotsionaalsed (spordi)skandaalid, nagu dopingukasutamine ja sellega seotud valetamine ja varjamine, põhjustavad universaalseid reaktsioone, kuid need on kohandatud vastavalt kohalikule kontekstile kultuurisemiootilise tõlke mehhanismide kaudu. Meemid purjetavad praegu oma populaarsuse laineharjal ja levivad kiiresti kaugemale kui kunagi varem, seetõttu tuleb nende loomise, levitamise, populaarsuse ning kohanemise uurimisel veel palju teha. Eckart Voigtsi (2017) eeskujul peaks tulevikus rohkem keskenduma meemide levitamise protsessi performatiivsele aspektile, samal ajal kui tekstilistele võrdlustele ja hermeneutilisele lähenemisele tuleks eelistada tekstide leviku, levitamise, tõlkimise ja esitamise uurimist.

\section{Tänusõnad}

Kirjutis on seotud Eesti Kirjandusmuuseumi uurimisprojektiga EKM 8-2/20/3 "Folkloori narratiivsed ja uskumuslikud aspektid", selle valmimist toetas Euroopa Liit Euroopa Regionaalarengu Fondi kaudu (Eesti-uuringute Tippkeskus, TK 145).

\section{Arhiiviallikad}

Eesti Kirjandusmuuseumi folkloristika osakonna teadusarhiiv EFITA (kataloog EFITA F02-015).

\section{Kirjandus}

Attardo, Salvatore 1994. Linguistic Theories of Humor. Berlin: Mouton de Gruyter.

Attardo, Salvatore \& Hempelmann, Christian \& Di Maio, Sara 2002. Script Opposition and Logical Mechanisms: Modeling Incongruities and Their Resolutions. Humor. International Journal of Humor Research 15 (1), lk 3-46 (doi: 10.1515/humr.2002.004).

Berger, Jonah \& Milkman, Katherine L. 2012. What Makes Online Content Viral? Journal of Marketing Research 49 (2), lk 192-205 (doi: 10.1509/jmr.10.0353). 
Blank, Trevor 2016. Giving the 'Big Ten' a Whole New Meaning: Tasteless Humor and the Response to the Penn State Sexual Abuse Scandal. Foster, Michael Dylan \& Tolbert, Jeffrey A. (toim). The Folkloresque: Reframing Folklore in a Popular Culture World. Logan: Utah State University Press, lk 179-204.

Burroughs, Benjamin \& Vogan, Travis 2015. Media Industries and Sport Scandals: Deadspin, Sports Illustrated, ESPN, and the Manti Te'o Hoax. International Journal of Sport Communication 8 (1), lk 87-102 (doi: 10.1123/IJSC.2014-0060).

Börzsei, Linda K. 2013. Makes a Meme Instead: A Concise History of Internet Memes. New Media Studies Magazine 162 (http://works.bepress.com/linda_borzsei/2 - 27. aprill 2020).

Cannizzaro, Sara 2013. Where Did Information Go? Reflections on the Logical Status of Information in a Cybernetic and Semiotic Perspective. Biosemiotics 6 (1), lk 105-123 (doi: 10.1007/s12304-012-9154-4).

Cannizzaro, Sara 2016. Internet Memes as Internet Signs: A Semiotic View of Digital Culture. Sign System Studies 4 (44), lk 562-586 (doi: 10.12697/SSS.2016.44.4.05).

Chiaro, Delia 2018. The Language of Jokes in the Digital Age. \#like \#share \#lol. Abingdon \& New York: Routledge.

Chiaro, Delia \& De Bonis, Giuseppe 2019. An Austrian in Hollywood: The Representation of Foreigners in the Films of Billy Wilder. European Journal of Humour Studies 7 (1), lk 7-23 (doi: 10.7592/EJHR2019.7.1.chiaro).

Coscia, Michele 2013 Competition and Success in the Meme Pool: A Case Study on Quickmeme.com. Proceedings of the Seventh International AAAI Conference on Weblogs and Social Media. Palo Alto, California: AAAI Press, lk 100-109.

Cronin, Michael 2003. Translation and Globalization. London: Routledge.

Delabastita, Dirk 2002. A Great Feast of Languages: Shakespeare's Multilingual Comedy in 'King Henry V' and the Translator. The Translator 8 (2), lk 303-340 (doi: 10.1080/1 3556509.2002.10799136).

Dore, Margherita 2019. Editorial: Multilingual Humour in Translation. European Journal of Humour Studies 7 (1), lk 1-6 (doi: 10.7592/EJHR2019.7.1.dore1).

Dundes, Alan 1964. Texture, Text, and Context. Southern Folklore Quarterly 28, lk 251265.

Even-Zohar, Itamar 1986. Literary System. Sebeok, Thomas Albert (toim). Encyclopedic Dictionary of Semiotics. Berlin: Mouton de Gruyter, lk 463-466.

Frank, Russell 2011. Newslore: Contemporary Folklore on the Internet. Jackson: University Press of Mississippi.

Gumkowska, Anna \& Toczyski, Piotr 2016. Global Digital Genre-Communication Forms in the Process of Flow to Local Polish Memosphere: The Case of Facebook Art Memes. Studies in Global Ethics and Global Education 5, lk 39-71 (doi: 10.5604/23920890.1215489).

Highfield, Tim 2015. Tweeted Joke Life Spans and Appropriated Punch Lines: Practices Around Topical Humor on Social Media. International Journal of Communication 9, lk 2713-2734. 
Highfield, Tim \& Leaver, Tama 2016. Instagrammatics and Digital Methods: Studying Visual Social Media, From Selfies and GIFs to Memes and Emoji. Communication Research and Practice 2 (1), lk 47-62 (doi: 10.1080/22041451.2016.1155332T).

Hjorth, Larissa \& Burgess, Jean 2014. Intimate Banalities: The Emotional Currency of Shared Camera Phone Images During the Queensland Flood Disaster. Goggin, Gerard \& Hjorth, Larissa (toim). The Routledge Companion to Mobile Media. London: Routledge, lk 499-513 (https://www.academia.edu/7560145/INTIMATE_BANALITIES_ The_Emotional_Currency_of_Shared_Camera_Phone_Images_During_the_Queensland_ Flood_Disaster_by_Larissa_Hjorth_and_Jean_Burgess - 27. aprill 2020).

Johann, Michael \& Bülow, Lars 2019. One Does Not Simply Create a Meme: Conditions for the Diffusion of Internet Memes. International Journal of Communication 13, lk 1720-1742 (https://ijoc.org/index.php/ijoc/article/download/9169/2622 - 27. aprill 2020).

Jorgensen, Jeana 2017. Biden His Time: Joe Biden as Trickster in Political Memes. Presentation held at the AFS (American Folklore Society) conference in Minneapolis, Minnesota, 18-21 October 2017, 124 (https://cdn.ymaws.com/www.afsnet.org/resource/ resmgr/AM17/AFS17_Full_program_book.pdf - 27. aprill 2020).

Kim, Hyun Suk 2015. Attracting Views and Going Viral: How Message Features and News-Sharing Channels Affect Health News Diffusion. Journal of Communication 65 (3), lk 512-534 (doi: 10.1111/jcom.12160).

King, Larry 2005. Interview with Lance Armstrong. CNN. Larry King Live, 25. august (http://transcripts.cnn.com/TRANSCRIPTS/0508/25/lkl.01.html - 27. aprill 2020).

Knobel, Michele \& Lankshear, Colin 2007. Online Memes, Affinities, and Cultural Production. Knobel, Michele \& Lankshear, Colin (toim). A New Literacies Sampler. New York: Peter Lang, lk 199-239.

Know Your Meme = https://knowyourmeme.com/memes/hitlers-downfall-parodies 27. aprill 2020.

Kristeva, Julia 1984. Revolution in Poetic Language. New York: Columbia University Press.

Kuipers, Giselinde 2005. Where Was King Kong When We Needed Him? Public Discourse, Digital Disaster Jokes, and the Functions of Laughter after 9/11. The Journal of American Culture 28 (1), lk 70-84 (doi: 10.1111/j.1542-734X.2005.00155.x).

Laineste, Liisi \& Voolaid, Piret 2016. Laughing Across Borders: Intertextuality of Internet Memes. European Journal of Humour Research 4 (4), lk 26-49 (doi: 10.7592/ EJHR2016.4.4.laineste).

Leavitt, Alex 2013. From \#FollowFriday to \#YOLO: Exploring the Cultural Salience of Twitter Memes. Weller, Katrin \& Bruns, Axel \& Burgess, Jean \& Mahrt, Merja \& Puschmann, Cornelius (toim). Twitter and Society. New York: Peter Lang, lk 137-154.

Lessig, Lawrence 2008. Remix: Making Art and Commerce Thrive in the Hybrid Economy. New York: Penguin Press. 
Lotman, Juri 1992 [1984]. Semiosfäärist. Akadeemia 10, lk 2019-2043 (https://www. digar.ee/arhiiv/nlib-digar:101280 - 27. aprill 2020).

Lotman, Yuri 2001 [1990]. Universe of the Mind: A Semiotic Theory of Culture. London: I. B. Tauris.

Lu, Jackson G. \& Martin, Ashley E. \& Usova, Anastasiya \& Galinski, Adam D. 2019. Creativity and Humor Across Cultures: Where Aha Meets Haha. Luria, Sarah R. \& Baer, John \& Kaufman, James C. (toim). Creativity and Humor. Explorations in Creativity Research. London: Elsevier, lk 183-203 (doi: 10.1016/B978-0-12-813802-1.00009-0).

Milner, Ryan 2013. Hacking the Social: Internet Memes, Identity Antagonism, and the Logic of Lulz. The Fiberculture Journal (FCJ-156) 22 (http://twentytwo.fibreculturejournal. org/fcj-156-hacking-the-social-internet-memes-identity-antagonism-and-the-logic-oflulz/ - 27. aprill 2020).

Miltner, Kate M. \& Highfield, Tim 2017. Never Gonna GIF You Up: Analyzing the Cultural Significance of the Animated GIF. Social Media + Society 3 (3), lk 1-11 (doi: 10.1177/2056305117725223).

Nissenbaum, Adsaf \& Shifman, Limor 2018. Meme Templates as Expressive Repertoires in a Globalizing World: A Cross-linguistic Study. Journal of Computer-Mediated Communication 23 (5), lk 294-310 (doi: 10.1093/jcmc/zmy016).

Robertson, Ronald 1995. Glocalization: Time-Space and Homogeneity-Heterogeneity. Featherstone, Mike \& Lash, Scott \& Robertson, Ronald (toim). Global Modernities. London: Sage Publications, lk 25-44 (doi: 10.4135/9781446250563.n2).

Sebeok, Thomas A. 1991 [1988]. A Sign is Just a Sign. Bloomington: Indiana University Press.

Szerszunowicz, Joanna 2018. Typowy Janusz and Bad Luck Brian: On Meme Characters From a Cross-linguistic and Cross-cultural Perspective. European Journal of Humour Studies 6 (2), lk 3-22 (doi: 10.7592/EJHR2018.6.2.230.szerszunowicz).

Shifman, Limor 2007. Humor in the Age of Digital Reproduction: Continuity and Change in Internet-based Comic Texts. International Journal of Communication 1, lk 187-209.

Shifman, Limor 2014. Memes in Digital Culture. Cambridge, MA: MIT Press.

Shifman, Limor \& Thelwall, Mike 2009. Assessing Global Diffusion with Web Memetics: The Spread and Evolution of a Popular Joke. Journal of the American Society for Information Science and Technology 60 (12), lk 2567-2576 (doi: 10.1002/asi.21185).

Shifman, Limor \& Levy, Hadar \& Thelwall, Mike 2014. Internet Jokes: The Secret Agents of Globalization? Journal of Computer-Mediated Communication 19, lk 727-743 (doi: 10.1111/jcc4.12082).

Takovski, Aleksandar 2016. The Humor of Skopje 2014: Between Effects and Evaluations. Humor. International Journal of Humor Research 29 (3), lk 381- 412 (doi: 10.1515/ humor-2016-0022).

TED, 10. aprill 2013. Twitter.com (https://twitter.com/hilariousted/ status/322217455680356352 - 27. aprill 2020). 
Veszelszki, Ágnes 2014. Information Visualization: Infographics from a Linguistic Point of View. Benedek, András \& Nyíri, Kristóf (toim). The Power of the Image. Series Visual Learning 4. Frankfurt: Peter Lang, lk 99-109.

Vis, Farida \& Faulkner, Simon \& Parry, Katy \& Manykhina, Yana \& Evans, Lisa 2013. Twitpic-ing the Riots: Analysing Images Shared on Twitter During the 2011 UK Riots. Weller, Katrin \& Bruns, Axel \& Burgess, Jean \& Mahrt, Merja \& Puschmann, Cornelius (koost). Twitter and Society. New York: Peter Lang, lk 385-398.

Voigts, Eckart 2017. Memes and Recombinant Appropriation: Remix, Mashup, Parody. Leitch, Thomas (toim). The Oxford Handbook of Adaptation Studies. Oxford: Oxford University Press, lk 285-304 (doi: 10.1093/oxfordhb/9780199331000.013.16).

Voolaid, Piret 2014. Olümpiavõitja kui rahvuskangelane: folkloristlik vaade ühele dopingujuhtumile. Mäetagused 58, lk 53-84 (doi: 10.7592/MT2014.58.voolaid).

Voolaid, Piret 2017. Eesti rahvussport - suurtest narratiividest variatiivse ja humoorika/ iroonilise rahvaretoorikani. Mäetagused 69, lk 109-132 (doi: 10.7592/MT2017.69.voolaid).

Voolaid, Piret \& Laineste, Liisi 2013. We Believe! Online Representations of the Olympic Winner as a Mythic Hero. Folklore: Electronic Journal of Folklore 54, lk 9-38 (doi: 10.7592/FEJF2013.54.voolaid_laineste).

Värv, Maarja 2013. Andreas Veerpalu loodab isa jälgedes käia. Postimees 21. jaanuar (https://sport.postimees.ee/1110672/andreas-veerpalu-loodab-isa-jalgedes-kaia

27. aprill 2020).

Wertsch, James V. 2002. Voices of Collective Remembering. Cambridge: Cambridge University Press.

\section{Summary}

\section{From taboo to communication: Doping humour in culture dialogue}

\section{Liisi Laineste}

Senior Research Fellow

Department of Folkloristics, Estonian Literary Museum, Estonia

liisi.laineste@folklore.ee

\section{Piret Voolaid}

Senior Research Fellow

Department of Folkloristics, Estonian Literary Museum, Estonia piret.voolaid@folklore.ee

Keywords: Armstrong, cultural-semiotic translation, doping lore, folklore, humour, sports memes, Veerpalu

The Internet affects the adaption and translation of humour through faster dissemination, but also by influencing the content. This influence is especially palpable in 
languages that recycle - adapt and translate - texts from mostly English-language jokelore and meme pools.

This article gives an overview of humorous memes created in response to taboo and concealment of two doping scandals (Lance Armstrong in 2012, and cross-country skiers in February 2019). The authors compare the two corpora from a global and local perspective in order to pinpoint repeating and diverging patterns and to understand the mechanisms of humour. The two cases serve as an example of the process of cultural translation and express the tension of the local and the global. The analysis is informed by Limor Shifman's approach to memes and Sara Cannizzaro's cultural-semiotic translation theory, which see cultural adaptation as a folkloric and creative process.

The study addresses the following questions: Which topics repeat globally and which are local? Which global and local popular cultural narratives are used in constructing the memes? How well do memes "translate" from global to local contexts? What are the main reasons for untranslatability? What mechanisms are frequently used to deliver a humorous effect? The replies to these questions will help explicate meme adaptation as an important element in the process of cultural translation. Overall, the authors propose that meme mechanisms have an equal potential in different languages, regardless of the number of people who speak the language.

Liisi Laineste on Eesti Kirjandusmuuseumi folkloristika osakonna vanemteadur. Peamised uurimissuunad on kaasaegne, mh etniline rahvahuumor, internetifolkloor ja emotsioonide väljendamine digitaalses meedias. Ta on Eesti-uuringute Tippkeskuse nüüdiskultuuri (sh meedia) töörühma üks juhtidest. Andnud välja hulgaliselt artikleid, toimetanud kogumikke ja ajakirjade erinumbreid huumori, aga ka kuulujuttude, visuaalse kommunikatsiooni ja igapäevasuhtluse kohta.

Liisi Laineste is Senior Research Fellow at the Department of Folkloristics of the Estonian Literary Museum and one of the heads of the working group of contemporary culture (incl. the media) at the Centre of Excellence in Estonian Studies. Her main research subject is folk humour and its different manifestations on the Internet and elsewhere. She has published articles on ethnic humour, internet folklore, caricatures, and vernacular communication. Recently she has co-edited special issues of journals about communication styles (with W. Chłopicki, 2019) as well as the works of Christie Davies within the area of humour studies (with Sharon Lockyer, 2019), and published articles that deal with humorous memes, ethnic jokes and their globalization, and online rumours.

liisi.laineste@folklore.ee 
Piret Voolaid on Eesti Kirjandusmuuseumi folkloristika osakonna vanemteadur, Eesti-uuringute Tippkeskuse tegevjuht. Peamised uurimisteemad on folkloori lühivormid (mõistatuste liigiline mitmekesisus ja sotsiokultuurilised kontekstid, vanasõnade kaasaegsed kasutuskontekstid), laste- ja noortefolkloor kui ühiskondlike muutuste ja hoiakute indikaator, meediafolkloor, sh interneti sotsiaalmeedia ilmingud, multimodaalsed ja visuaalsed folkloorivormid (nt paröömiline grafiti, piltmõistatused) kui nüüdisühiskonna sünkreetilised kultuurinähtused. Viimastel aastatel on tegelenud spordifolkloristika ehk spordifolkloorile keskenduva uurimissuuna arendamisega, analüüsides dopingufolkloori, spordi rolli identiteedinarratiiivide konstrueerimisel. Koostanud mitmeid folkloori lühivormide andmebaase, avaldanud teadusartikleid, toimetanud artiklikogumikke ja ajakirjade erinumbreid.

Piret Voolaid is Senior Research Fellow at the Department of Folkloristics of the Estonian Literary Museum, and an Executive Manager of the Centre of Excellence in Estonian Studies. She defended her PhD ("Estonian Riddles as a Folklore Genre in a Changing Cultural Context") in the field of Estonian and comparative folklore at the University of Tartu in 2011. Her current interests include minor forms of folklore (subgenres of Estonian riddles, proverbs in their various contemporary contexts), children's and youth folklore, Internet, and sports lore. She has compiled academic comprehensive databases of the subgenres of riddles (droodles, joking questions, compound puns, abbreviation riddles, etc.), and a database of graffiti. She has written several studies on the topic and compiled popular editions on the basis of the database materials. She has guest-edited special issues of the journals Folklore: EJF and Mäetagused, and has been editor of some monographs.

piret.voolaid@folklore.ee 